\title{
Role of membrane biophysics in Alzheimer's-related cell pathways
}

\author{
Donghui Zhu ${ }^{1}$, Brittani L. Bungart ${ }^{2}$, Xiaoguang Yang ${ }^{3,4}$, Zhaxybay Zhumadilov ${ }^{5}$, \\ James C-M. Lee ${ }^{6}$ and Sholpan Askarova ${ }^{5 *}$ \\ 1 Department of Chemical, Biological and Bioengineering, North Carolina A\&T State University, Greensboro, NC, USA, \\ ${ }^{2}$ Indiana University School of Medicine Medical Scientist Training Program, Indiana University School of Medicine, \\ Indianapolis, IN, USA, ${ }^{3}$ Department of Clinical Neuroscience and Rehabilitation, Institute of Neuroscience and Physiology, \\ Sahlgrenska Academy at University of Gothenburg, Gothenburg, Sweden, ${ }^{4}$ The Hope Center for Neurological Disorders and \\ Department of Neurology, Washington University School of Medicine, St. Louis, MO, USA, ${ }^{5}$ Department of Bioengineering \\ and Regenerative Medicine, Center for Life Sciences, Nazarbayev University, Astana, Kazakhstan, ${ }^{6}$ Department of \\ Bioengineering, University of Illinois at Chicago, Chicago, IL, USA
}

OPEN ACCESS

Edited by:

Ritchie Williamson University of Dundee, UK

Reviewed by:

Harish Pant,

National Institute of Neurological Disorders and Stroke, National Institutes of Health, USA

Ling $L i$,

University of Minnesota, USA

*Correspondence:

Sholpan Askarova,

Department of Bioengineering and Regenerative Medicine, Center for Life

Sciences, Nazarbayev University, 53

Kabanbay Batyr Avenue, Astana, 010000 Kazakhstan shaskarova@nu.edu.kz

Specialty section: This article was submitted to Neurodegeneration, a section of the journal Frontiers in Neuroscience

Received: 18 February 2015 Accepted: 11 May 2015 Published: 27 May 2015

Citation:

Zhu D, Bungart BL, Yang $X$,

Zhumadilov Z, Lee JC-M and Askarova S (2015) Role of membrane biophysics in Alzheimer's-related cell pathways. Front. Neurosci. 9:186. doi: 10.3389/fnins.2015.00186
Cellular membrane alterations are commonly observed in many diseases, including Alzheimer's disease (AD). Membrane biophysical properties, such as membrane molecular order, membrane fluidity, organization of lipid rafts, and adhesion between membrane and cytoskeleton, play an important role in various cellular activities and functions. While membrane biophysics impacts a broad range of cellular pathways, this review addresses the role of membrane biophysics in amyloid- $\beta$ peptide aggregation, $A \beta$-induced oxidative pathways, amyloid precursor protein processing, and cerebral endothelial functions in AD. Understanding the mechanism(s) underlying the effects of cell membrane properties on cellular processes should shed light on the development of new preventive and therapeutic strategies for this devastating disease.

Keywords: amyloid- $\beta$ peptide, amyloid precursor protein, membrane molecular order, membrane fluidity, cerebral endothelium

\section{Introduction}

Alzheimer's disease will claim 13.2 million Americans by 2050 if no preventive treatments are found. The increasing number of $\mathrm{AD}$ victims puts a heavy economic and emotional burden on society, and thus $\mathrm{AD}$ has become an urgent national health and research priority. $\mathrm{AD}$ is complicated and multi-factorial involving numerous etiopathogenic mechanisms. Therefore, it is unlikely that any one single intervention well be efficacious to delay, prevent, or cure it. Many mechanisms involved in the pathogenesis and pathophysiology of AD have yet to be elucidated. In fact, recent studies provide strong evidence that cell membrane composition and cell biophysics play an important role in a number of pathophysiological events in AD (Hicks et al., 2012).

Cellular membrane lipid composition is dynamically changing and correlated with the progression of AD (Frisardi et al., 2011). In addition, alterations of membrane cytoskeleton may change the mechanical properties of cells and cell membranes, leading to eventual changes of cell functions, such as adhesion. Although, recent research findings show that the influences of membrane lipids and properties have been proven in many cellular pathways and processing implicated in $\mathrm{AD}$, the role of altered lipid composition and membrane properties in the disease has yet to be fully elucidated.

Another important area of research investigates which aggregated forms of amyloid- $\beta$ peptide $(\mathrm{A} \beta)$ are involved in the pathogenesis of AD. In fact, recent studies provide evidence showing that $\mathrm{A} \beta$ oligomers trigger many downstream oxidative pathways and neuro-inflammation 
(Salminen et al., 2009; Hodgson et al., 2013; Meraz-Rios et al., 2014). In this review, we address $A \beta$-related cellular processes in their relation to the physical properties of the cell membranes. Specifically, we summarize the role of biophysical factors in $A \beta$ aggregation and the effects of oxidative stress and $A \beta$ on membrane biophysics, membrane biophysics on amyloid precursor protein (APP) processing, and membrane mechanics in altered endothelial functions and blood brain barrier (BBB).

\section{The Biophysics of A $\beta$ Aggregation}

Amyloidogenic processing of the APP by $\beta$ - and $\gamma$-secretase leads to the production of $\mathrm{A} \beta$ monomers of different lengths, of which the $A \beta_{1-40}$ is the major species and the $A \beta_{1-42}$ is the most fibrillogenic and predominant component in $\mathrm{AD}$ plaques (Bernstein et al., 2005). $A \beta_{1-40}$ and $A \beta_{1-42}$ consist of hydrophilic $\mathrm{N}$-terminal regions (residues 1-28) and hydrophobic C-terminal regions (residues $29-40$ or 29-42), which is originally the part of a transmembrane $\alpha$-helix of APP (Figure 1). In vitro studies have demonstrated that $\mathrm{A} \beta$ monomers can exist in three major conformation forms: $\alpha$-helix, $\beta$-sheet or random coil (Liu et al., 2006). Since the fibrils mostly consist of $\beta$-sheets, while the original hydrophobic part of $A \beta$ is an $\alpha$-helix, the conformational transition of $A \beta$ from $\alpha$-helix to $\beta$-sheet probably is the very first step in fibril formation, and there is evidence that conformational transitions of $\mathrm{A} \beta$ monomers depend on physical and chemical parameters of the environment. For example, in aqueous solution $A \beta$ exists as a mixture of all three conformation forms; in fluorinated alcohols, as well as at $\mathrm{pH} \mathrm{1-4} \mathrm{and} \mathrm{7-10,}$ $\mathrm{A} \beta$ exists in a form of $\alpha$-helix, while $\beta$-sheet favored at $\mathrm{pH} 4$ 7 (Liu et al., 2006). In turn, the hydrophobic and positively charged self-assembled lipid monolayers (SAM) induce more $\mathrm{A} \beta$ adsorption, faster $\beta$-sheet formation, and stronger binding affinity than the hydrophilic and the negatively charged SAM. All of them accelerate $A \beta$ aggregation and promote the structural conversion from an unstructured conformation to a $\beta$-sheetcontaining structures compared to neutral solutions (Wang et al., 2011).

The next step in a process of $A \beta$ aggregation is forming hydrogen bonds between the amide and the carbonyl (check spell) groups of anti-parallel oriented $\beta$-sheets with further aggregation into higher order structures (Poduslo and Howell, 2015). The aggregation of $A \beta$ into fibrils is a complicated multi-step process that occurs through a number of intermediate structural forms and can be described as a sequential process consisting of several phases: monomers $\rightarrow$ misfolded monomers $\rightarrow$ soluble oligomers (clusters of small numbers of peptide molecules without a fibrillar structure) $\rightarrow$ protofibrils (aggregates of isolated or clustered spherical beads made up of $\sim 20$ molecules with $\beta$-sheet structure) $\rightarrow$ mature fibrils (Sengupta et al., 2014) (Figure 1).

There is evidence that the formation of $A \beta$ fibrils is a nucleation-depended process. The conversion of a peptide into a fibril includes a lag phase that reflects the thermodynamic barrier to the formation of a nucleus followed by a rapid growth phase involving the sequential incorporation of $\mathrm{A} \beta$ peptides,

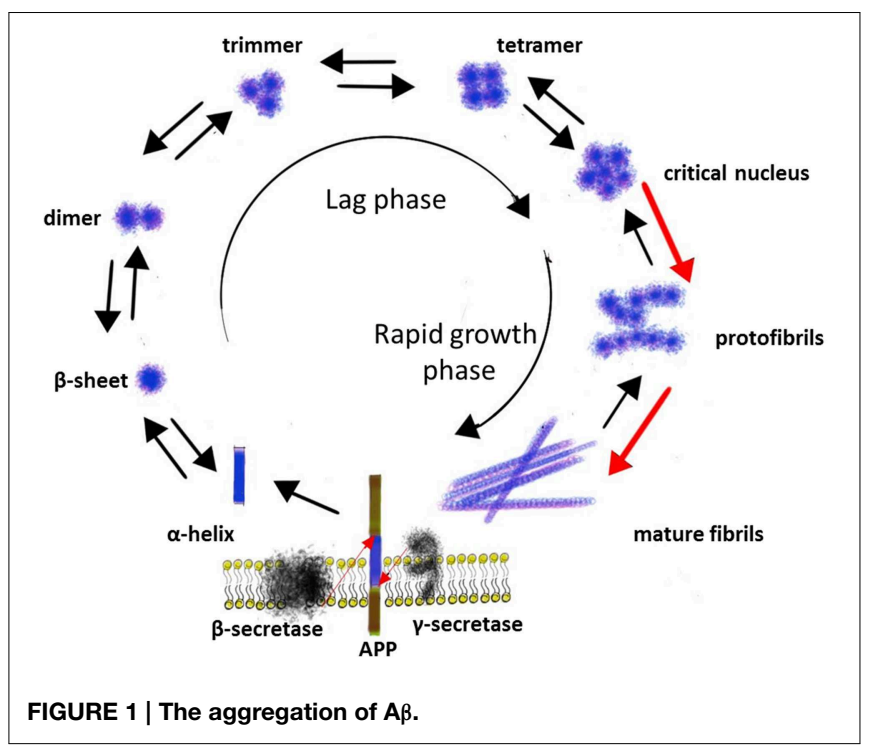

producing rigid structures consisting of several layers of cross$\beta$ sheets. Several studies indicated that monomer, dimer, trimer, and tetramer species of $A \beta$ exist in a rapid equilibrium, while pentameric or hexameric aggregates form a critical nucleus for higher order assembly (Figure 1) (Mclaurin et al., 2000; Chiti and Dobson, 2006).

Several studies have indicated that the size and the shape of $\mathrm{A} \beta$ aggregates, as well as the kinetics of their formation, depend on the physicochemical nature of the surface. For example, on hydrophilic surface (mica) A $\beta$ formed particulate, pseudomicellar aggregates, while on hydrophobic surface $A \beta$ formed uniform, elongated sheets with the dimensions consistent of $\beta$-sheets (Kowalewski and Holtzman, 1999). These studies suggest that $A \beta$ fibril formation may be driven by interactions at the interface of aqueous solutions and hydrophobic substrates, as occurs in membranes and lipoprotein particles in vivo (Kowalewski and Holtzman, 1999; Ban et al., 2006; Wang et al., 2011). In turn, metal ions have been shown to play a role in $A \beta$ aggregation. Some studies have indicated that very low levels of copper and zinc initiate seeding and oligomerization of $A \beta$ and accelerate fibril formation by unfolding the helical structure in $\mathrm{A} \beta$ peptide and stabilizing the formation of vital salt-bridges within and between $A \beta$ peptides (Mclaurin et al., 2000; Pan and Patterson, 2013). Calcium has been also shown to accelerate both the formation of protofibrils and its conversion to fibrills (Isaacs et al., 2006). On the other hand, there is evidence that many membrane associated proteins and glycolipids can regulate $\mathrm{A} \beta$ conformation and aggregation in both enhancement and inhibition manner as well (Mclaurin et al., 2000). For example, the binding of $\mathrm{A} \beta$ to the membrane sialoglycolipid GM1 ganglioside can lead to a conformational change in $A \beta$ and seeding of aggregation (Manna and Mukhopadhyay, 2013). $\mathrm{A} \beta$ interactions with phospholipids can also induce a structural transition from random coil to $\beta$-sheet in $A \beta 40 / 42$ and $A \beta 25$ 35 , increase the local peptide concentration (in a vesicular environment) and accelerate fibril formation (Yuyama et al., 2008). 
Thus, aggregation of $A \beta$ is a multistep process which can be modulated by physical and chemical factors such as conformation of $\mathrm{A} \beta, \mathrm{pH}$, electrical charge, hydrophilicity, or hydrophobicity of the environment, and interaction with other elements that either promote or inhibit $\mathrm{A} \beta$ aggregation (Mclaurin et al., 2000). Identification of these factors and understanding the driving forces behind these interactions will help to reveal new therapeutic targets for prevention of amyloid formation and its associated toxicity (Mckoy et al., 2012; Luo et al., 2014; Yang et al., 2014). Since aggregation of $A \beta$ occurs mainly at the surface of the cell membranes in next chapter the influence of the cell membrane's composition and biophysics on $\mathrm{A} \beta$ aggregation will be discussed.

\section{Aggregation of $A \beta$ Peptide is Influenced by the Membrane's Composition and Biophysics}

The cellular membrane is known to be a highly dynamic structure with different lateral phases, which are mostly dependent upon membrane composition, but also temperature and $\mathrm{pH}$ if a deviation from physiological condition is present (Heberle and Feigenson, 2011). One of these phases, commonly referred to as the lipid raft, has a high molecular order which is more tightly packed than non-raft domains due to intermolecular hydrogen bonding involving sphingolipids and cholesterol (Barenholz, 2004; Fantini and Yahi, 2010). They are also known to be the platform for the assembly of many signaling molecules.

The formation of these microdomains is attributed to the protein-protein and protein-lipid synergy, which induces the observed high molecular order (Pike, 2006). For example, cholesterol, found in substantial concentrations in lipid rafts, is known to decrease lateral lipid diffusion, while increasing the surface hydrophobicity (Yu and Zheng, 2012). In the bilayer membrane and vesicle models, lipid rafts are found to coexist with fluid lipid regions, which are composed mainly of homogenous phosphatidylcholine (PC) and cholesterol (Dietrich et al., 2001).

In the pathology of $\mathrm{AD}$, lipid rafts are known to be the main location for the interaction of $\mathrm{A} \beta$ with the cellular membrane (Kim et al., 2006; Choucair et al., 2007; Williamson et al., 2008; Cecchi et al., 2009; Ogawa et al., 2011; Mazargui et al., 2012). Two of the components of lipid rafts, cholesterol and the ganglioside called monosialotetrahexosylganglioside (GM1), have been given most of the spotlight in this interplay. Due to shingolipids having saturated fatty acids as side chains and cholesterol being able to pack closely with them, lipid rafts are of a higher order and have less fluid in the hydrophobic region than the surrounding domains (Thakur et al., 2011). Cholesterol then, in turn, is important in regulating the formation and function of lipid rafts and in increasing the concentration of GM1 in these microdomains (Cecchi et al., 2009).

When the cholesterol concentration is manipulated, a noticeable difference in the cellular membrane's influence on $A \beta$ occurs. The concentration of cholesterol in lipid rafts correlates to the adsorption of $A \beta_{1-42}$ on a 1-palmitoyl,2-oleoyl-sn-glycero3-phosphocholine bilayer, while having little affect in a dipalmitoylphosphatidylglycerol bilayer model (Thakur et al., 2011). Any change in the cholesterol of the cellular membrane in human neuroblastoma cells results in causing $A \beta_{1-42}$ oligomers to react differently with the bilayer (Williamson et al., 2008). In fact, it has been reported that a higher cholesterol content in the bilayer leads to increased membrane rigidity, which is more favorable for $A \beta$-membrane interactions, and a concomitant increase in the accumulation of $\mathrm{A} \beta_{1-42}$ (Yip et al., 2002).

When $A \beta$ adsorbs or inserts into the membrane bilayer, the peptide-lipid interactions make the secondary and tertiary structure change to a more energetically favorable configuration (Zhao et al., 2011). A $\beta$ was also observed to accumulate in size from monomer to hexamer and beyond, with the majority of the aggregates' size in the dimer to tetramer range. In comparison of the size of aggregate created in and not in the presence of cellular membrane, the larger aggregates are formed when the cell membrane is involved (Johnson et al., 2011). In neutral solution, $\mathrm{A} \beta$ consists of mostly alpha-helix or random coil. When $A \beta$ is incubated with lipid rafts acquired from rat neuronal cells, cholesterol affects the conversion of the $\alpha$-helix conformation of $A \beta$ to the $\beta$-sheet-rich structure, which is synonymous with toxicity (Zhao et al., 2011).

Molecular dynamics (MD) simulations uncovered another vindication for the confirmation change of $A \beta_{1-40}$ and $A \beta_{1-42}$. The presence of GM1 amplifies the conversion of the $\alpha$-helix to principally $\beta$-sheets through the formation of beta-hairpins at the C-terminal (Ogawa et al., 2011). This dependence on GM1 was confirmed when $5 \mu \mathrm{M} \mathrm{A} \beta_{1-42}$ preferentially aggregates in vicinity to GM1-liposomes. On the other hand, $5 \mu \mathrm{M}$ $\mathrm{A} \beta_{1-40}$ did not aggregate under these conditions, showing that $\mathrm{A} \beta_{1-40}$ and $\mathrm{A} \beta_{1-42}$ interact dissimilarly with cellular membrane (Ogawa et al., 2011). In fact, $A \beta_{1-42}$ accumulates more than $\mathrm{A} \beta_{1-40}$ in mice brains (Abramowski et al., 2012; Manna and Mukhopadhyay, 2013). Furthermore, in lipid rafts with no GM1, only a portion versus all of the membrane-associated $A \beta$ obtains the beta-sheet folds (Lemkul and Bevan, 2011).

GM1 has also undergone similar scrutiny as cholesterol in its capacity to induce $A \beta$ binding to the cell membrane. Gangliosides, such as GM1, have the ability to host the location for $A \beta$ to seed (Kakio et al., 2002; Mazargui et al., 2012) and are even required for oligomerization to occur, while lipid and cholesterol is not necessary (Kim et al., 2006). In mice neuronal cells, $A \beta$ was found to colocalize with GM1 (Williamson et al., 2008; Hong et al., 2014), which in fact can be partially inhibited by cholesterol (Williamson et al., 2008). Aggregation of $A \beta_{1-40}$ occurs during the co-incubation of $A \beta_{1-40}$ with raftlike liposomes containing GM1, cholesterol, and sphingomyelin. Additionally, aggregation is not elicited during the incubation of non-raft-like structures, such as GM1 with PC, but is when raft-like structures, such as cholesterol with GM1 and PC, are involved, further proving that $\mathrm{A} \beta$ depends upon an environment such as the lipid raft to cumulate (Okada et al., 2008).

Other factors in relation to the direct composition of the cellular membrane are investigated to determine their influence on $\mathrm{A} \beta$ adsorption and intercalation, such as the cell membrane's surface charge. Anionic areas in human neuroblastoma cellular membrane promote the interactions of $\mathrm{A} \beta_{1-40}$ (Johnson et al., 
2011), while aggregation is inhibited in the presence of vesicles with negatively charged surfaces. Adsorption of $A \beta_{1-40}$ is more likely to occur on a negatively charged surface, and with neutral membranes experience mostly insertion (Sabaté et al., 2012). This suggests that dynamic interactions mediate this, and it is not only dependent upon the negative charge of the membrane as shown in vesicle-model studies.

The cellular membrane's biophysics are central in the actions that $\mathrm{A} \beta$ undergoes, which can be explained by $\mathrm{A} \beta$ being an amphipathic molecule that will adsorb non-specifically at an air and water interface and penetrate into uncompressed monolayers formed by zwitterionic and anionic phospholipids (Relini et al., 2009). The influence of the biophysical parameters and cell membrane's composition on $\mathrm{A} \beta$ conformational state and aggregation is summarized in the Table 1. However, this is not a one-way interaction; $A \beta$ also influences the cellular membrane's biophysics, which will be discussed in the following chapter.

\section{The Membrane's Composition and Biophysics is Influenced by A $\beta$ Peptide and Oxidative Stress}

All of the aspects, which evoke the aggregation of $A \beta$, of the cell membrane's biophysics mentioned in the previous section can also be impacted due to $A \beta$ interacting with the cellular membrane. $\mathrm{A} \beta$ has been observed to alter the fluidity and molecular order of the cellular membrane, along with acting in a functional manner by having the ability to create a pore when insertion occurs. Other features are also affected that were not discussed, such as the conductance of the cell membrane and the orientation of the lipid tails and cholesterol.

When $A \beta$ integrates into the cellular membrane, an invagination causes voids, which fill with excess water and protein, engendering the cell membrane to become more molecularly disordered (Chang et al., 2010). In one scenario, $\mathrm{A} \beta_{1-42}$ causes an increase in the amount of water in the hydrophobic region of the bilayer in neuronal cells (Hicks et al., 2008). This alteration of the molecular order has been proposed to be the mechanism to explain the decrease in thickness of the lipid bilayer in the companionship of $A \beta$. By using MD simulations of $A \beta$ insertion into the membrane bilayer to observe the molecular effects, the electrostatic forces cause the most thermodynamically stable orientation for the lipids and cholesterol to be different. The adjacent cholesterol tilts, which is not observed in cholesterol that is far from $\mathrm{A} \beta$ (Zhao et al., 2011). The orientation of the lipid tails is also altered (Chang et al., 2010; Tofoleanu and Buchete, 2012)they significantly point away from the region during protofibril interaction (Tofoleanu and Buchete, 2012). This equates to the area per lipid and cholesterol increasing (Qiu et al., 2011). In human brains afflicted with AD compared to normal brains no alteration in the content of lipid rafts are observed (Martín et al., 2010). Even though the composition is not altered, the changes on the molecular level have a more important effect on the cellular membrane.
TABLE 1 | The influence of the cell membrane's composition and biophysics on $A \beta$ conformational state and aggregation.

\begin{tabular}{|c|c|c|c|}
\hline $\begin{array}{l}\text { Physical and } \\
\text { chemical } \\
\text { factors }\end{array}$ & $\begin{array}{l}\text { Conformational } \\
\text { state of } A \beta\end{array}$ & $\begin{array}{l}\text { Aggregation } \\
\text { of } A \beta\end{array}$ & References \\
\hline $\mathrm{pH} 1-4$ & $\beta$-sheet & $\uparrow$ & $\begin{array}{l}\text { Liu et al., 2006; } \\
\text { Bhowmik et al., } 2014\end{array}$ \\
\hline $\mathrm{pH} 7-10$ & $a ́$-helix & $\downarrow$ & $\begin{array}{l}\text { Liu et al., 2006; } \\
\text { Bhowmik et al., } 2014\end{array}$ \\
\hline Positive charge & $\beta$-sheet & $\uparrow$ & Wang et al., 2011 \\
\hline $\begin{array}{l}\text { Electrically } \\
\text { neutral } \\
\text { environment }\end{array}$ & $\alpha$-helix & $\downarrow$ & Wang et al., 2011 \\
\hline $\begin{array}{l}\text { Hydrophobic } \\
\text { environment }\end{array}$ & $\beta$-sheet & $\uparrow$ & Wang et al., 2011 \\
\hline $\begin{array}{l}\text { Hydrophilic } \\
\text { environment }\end{array}$ & $\dot{\alpha}$-helix & $\downarrow$ & $\begin{array}{l}\text { Kowalewski and } \\
\text { Holtzman, 1999; Liu } \\
\text { et al., 2006; Wang } \\
\text { et al., 2011 }\end{array}$ \\
\hline $\begin{array}{l}\text { Membrane } \\
\text { fluidity } \downarrow\end{array}$ & NA & $\uparrow$ & Yip et al., 2002 \\
\hline $\begin{array}{l}\text { Membrane } \\
\text { fluidity } \uparrow\end{array}$ & NA & $\downarrow$ & Yip et al., 2002 \\
\hline Cholesterol & $\beta$-sheet & $\uparrow$ & $\begin{array}{l}\text { Yip et al., 2002; } \\
\text { Schneider et al., 2006; } \\
\text { Zhao et al., } 2011\end{array}$ \\
\hline GM1 & $\beta$-sheet & $\uparrow$ & $\begin{array}{l}\text { Kim et al., 2006; } \\
\text { Ogawa et al., 2011; } \\
\text { Manna and } \\
\text { Mukhopadhyay, } 2013\end{array}$ \\
\hline Phospholipids & $\beta$-sheet & $\uparrow$ & Yuyama et al., 2008 \\
\hline Metal ions & unfold $\alpha$-helix & $\uparrow$ & $\begin{array}{l}\text { Mclaurin et al., 2000; } \\
\text { Isaacs et al., 2006; Pan } \\
\text { and Patterson, 2013; } \\
\text { Yang et al., } 2014\end{array}$ \\
\hline
\end{tabular}

$\uparrow$ denotes increase, $\downarrow$ denotes decrease, NC denotes no change, NA denotes data not available.

One of the effects observed is the change in the cell membrane's fluidity, which inflates due to $A \beta$ interaction (Hou et al., 2008; Khalifat et al., 2012; Liguori et al., 2013; Sasahara et al., 2013). In studies involving mitochondrial membrane vesicle model and rats, this was especially observed. The inner membrane of the mitochondria, which is the location of the final stage of ATP production, has cristae-like folds. These folds could not form in vitro under the influence of $\mathrm{A} \beta$ and may be due to the decrease in membrane fluidity and changes in dynamic friction of the cellular membrane (Khalifat et al., 2012). In vivo studies show similar findings, which reduced the function of cytochrome C oxidase (Hou et al., 2008). Finally, analysis of lipid raft microdomains in human $\mathrm{AD}$ brains elucidated that lipid rafts have a reduced unsaturated index and an increase in saturated fatty acids, resulting in more of the liquid-ordered phase and an increase in the cell membrane's viscosity (Martín et al., 2010). This parallels the stiffening, or Young's modulus, of the lipid bilayer, which has been shown to occur due to $A \beta_{1-42}$ oligomer (Lulevich et al., 2010). 
For neuronal cells the ability for the cell to be excited is important in relation to cognitive function. $A \beta_{1-42}$ oligomer can increase the bilayer membrane conductance in both model and cell membranes (Sokolov et al., 2006; Lioudyno et al., 2012), specifically shown through the kinetic properties of one voltage-gated ion channel, the $\mathrm{Kv} 1.3$ channel, being affected (Lioudyno et al., 2012). Besides directly affecting ion channels, the membrane itself is altered in Purkinje cells by soluble $A \beta_{1-42}$ and thus reduces the intrinsic membrane excitability (Hoxha et al., 2012). Both $A \beta_{1-40}$ (Sabaté et al., 2012) and $A \beta_{1-42}$ (Choucair et al., 2007) interacting with liposomes cause their membrane to become leakier. Only the soluble but not the fibrillar form of $A \beta$ can cause a change in the membrane conductance Sokolov et al., 2006; Sabaté et al., 2012. It has been proposed that this is due to a combination of the thinning, $A \beta$-induced local defects, and an increase in the dielectric constant of the cellular membrane, which varied due to the composition of the lipid and not by cholesterol. Negatively charged lipid reduces the effects that $\mathrm{A} \beta$ has on the membrane conductance, while neutral membrane has no influence. This was proposed to be due to electrostatic repulsion since $A \beta$ has a net charge of -3 (Sokolov et al., 2006). A theory has also been established stating that $A \beta$ can make a pore in certain conditions upon insertion into the cellular membrane. Pore formation has been shown to be thermodynamically feasible with MD simulations, in which a beta-barrel can take form in the bilayer to potentially increase the leakiness (Sabaté et al., 2012). This theory is not widely accepted though, but is still under consideration for potential mechanisms of action to elucidate the observation of the conductance and excitability changes.

The repercussions of $A \beta$ morph the healthy state of the cell in ways not limited to this review. The alterations to the membrane's biophysics upset the cell's normal function, which in turn evoke additional complications. While many of these issues induced by $\mathrm{A} \beta$ have been elucidated, a quandary still exists over the full understanding of membrane interactions of $\mathrm{A} \beta$ in $\mathrm{AD}$.

On the other hand, physical properties of cellular membranes are most likely altered in $\mathrm{AD}$ not only due to direct effects caused by $A \beta$, but also via downstream cellular signaling involving oxidative stress and $A \beta$-induced oxidant pathways. Reactive oxygen species (ROS) are generated in response to various physiologic or pathologic conditions, and is one of the pathological factors in Alzheimer's disease (AD). In addition to ROS produced extrinsically, a cell may produce ROS as a result of normal metabolism and signaling processes. When excess ROS are present within the cell, this oxidative stress may have profound deleterious effects on the cell, including the direct oxidation of biomolecules (e.g., lipid, protein, and DNA), indirect alteration in cellular structures and functions, and the induction of cell death. Direct interaction between ROS and the cell membrane can lead to the alteration of membrane biophysical properties, such as membrane molecular order and membrane fluidity. Our previous data demonstrated $\mathrm{H}_{2} \mathrm{O}_{2}$ made membranes more molecularly-ordered (or gel-like) in astrocytes and was a combined effect of direct oxidation and indirect alterations mediated by MAPK pathway (Zhu et al., 2005). Additional evidence showed that oxidant menadione also changed plasma membrane molecular order and fluidity, making it more gel-like (Zhu et al., 2006). Both NADPH oxidase and phospholipase $\mathrm{A}_{2}\left(\mathrm{PLA}_{2}\right)$ regulated such alterations in addition to direct oxidation from ROS.

Thus, cellular membrane's biophysics, defined here as the molecular order, fluidity or viscosity, and the surface charge, play a critical role in the manipulation of $A \beta$ 's confirmation, aggregation, and their direct interaction with the cell membrane. In turn, the residues of $A \beta$, which are $A \beta_{25-36}, A \beta_{1-40}, A \beta_{1-42}$, as well as reactive oxygen species, also affect the CM's biophysical properties (Table 2). These events are speculated to be one of the keys factors in the initiation of the $\mathrm{AD}$ cascade, therefore becoming a target for potential therapeutic strategies (Mckoy et al., 2012; Lee et al., 2014).

\section{Membrane Biophysics and Composition on APP Processing}

As discussed in the previous section, the physical properties of cellular membranes can be altered by $\mathrm{A} \beta$ interactions and $\mathrm{A} \beta$ induced cellular pathways. In turn, these membrane alterations can have an impact on cellular functions, such as amyloid precursor protein (APP) processing and cerebral endothelial adhesion and permeability.

Two competing processing pathways are currently known for APP. In the amyloidogenic pathway, $A \beta$ is derived from a proteolytic process of amyloid precursor protein (APP), in which APP is cleaved sequentially by $\beta$ - and $\gamma$-secretases (Haass et al., 2012). Alternatively, APP can be cleaved by $\alpha$-secretases between amino acids 16 and 17 within the $A \beta$ domain to produce neurotrophic and neuroprotective soluble APP $\left(\operatorname{sAPP}_{\alpha}\right)$ in the non-amyloidogenic pathway (Thornton et al., 2006). The enhancement of APP processing by $\alpha$-secretases has been suggested as a potential therapeutic strategy for AD (Cheng et al., 2007). Since APP, $\alpha$-, $\beta$-, and $\gamma$-secretases are membrane proteins, APP processing is affected by the local membrane environment. In this section, we review the evidence about the effects of fatty acids and cholesterol on membrane properties and APP

TABLE 2 | The influence of A $\beta$ on cell membrane's composition and biophysics.

\begin{tabular}{ll}
\hline Effects of $\mathbf{A} \boldsymbol{\beta}$ on cell membrane & References \\
\hline $\begin{array}{l}\text { Introduce voids, making membrane } \\
\text { more molecularly disordered }\end{array}$ & Chang et al., 2010 \\
$\begin{array}{l}\text { Increase } \mathrm{H}_{2} \mathrm{O} \text { in membrane, leading } \\
\text { to thinner lipid bilayer }\end{array}$ & Hicks et al., 2008 \\
Decrease in membrane fluidity & Hou et al., 2008; Khalifat et al., 2012; \\
& Liguori et al., 2013; Sasahara et al., \\
Increase in membrane viscosity & 2013 \\
Increase in membrane stiffness & Martín et al., 2010 \\
Increase in bilayer membrane & Lulevich et al., 2010 \\
conductance & Sokolov et al., 2006; Lioudyno et al., \\
Introduce leakage in membrane & 2012 \\
ROS induced by A $\beta$ make membrane & Choucair et al., 2007 \\
Zhu et al., 2005, 2006
\end{tabular}

more gel-like 
processing. Understanding the mechanisms leading to changes of membranes biophysics and how they result in changes in APP processing has the potential to provide insights into new therapeutic strategies for prevention and treatment of AD.

Fatty acids are important ingredients in various dietary sources and play a central role in the normal development and function of the brain (Dyall and Michael-Titus, 2008; Schuchardt et al., 2010). Long-chain $\omega-6$ and $\omega-3$ polyunsaturated fatty acids (PUFAs), the major polyunsaturated fatty acids in the central nervous system, are essential for prenatal brain development and normal brain functions (Uauy et al., 2001; Dyall and MichaelTitus, 2008). The disturbed metabolism of fatty acids is associated with AD. For instance, lower levels of docosahexaenoic acid (DHA) have been reported in serum samples taken from AD patients (Tully et al., 2003), while greater consumption of DHA has significantly reduced the likelihood of developing AD (Schaefer et al., 2006). In 15-month-old APP/PS1 mice, DHA supplementation improved spatial memory, decreases $\mathrm{A} \beta$ deposition, and slightly increased relative cerebral blood volume, indicating that a DHA-enriched diet could diminish AD-like pathology (Hooijmans et al., 2007). On the other hand, accumulation of trans fatty acids in the cellular membrane increased production and oligomerization of $A \beta$ (Grimm et al., 2011).

PUFAs in neuronal cells can influence cellular functions through effects on membrane properties (Hibbeln et al., 2000; Sinclair et al., 2007; Heinrichs, 2010). The ability of fatty acids to modulate membrane properties and functions depends on both the saturation degree of the fatty acids and the trans/cis ratio of the unsaturated fatty acids (Loffhagen et al., 2004; Yang et al., 2011). For example, diets enriched in unsaturated PUFAs, DHA, and AA, have been shown to increase membrane fluidity of neurons and other cells (Mclauren Dorrance et al., 2000; Horrocks and Farooqui, 2004; Hashimoto et al., 2006; Fukaya et al., 2007). DHA was capable of counteracting cholesterolinduced decrease in platelet membrane fluidity and modulating platelet hyperaggregation (Hashimoto et al., 2006). Similarly, cis-polyunsaturated linolenic, $\alpha$-linoleic, and eicosatrienoic fatty acids increased membrane fluidity (Kitagawa et al., 1990). In contrast, incorporation of saturated fatty acids into membrane led to decreased membrane fluidity (Calder et al., 1994).

It has been reported that an increase in membrane fluidity leads to an increase in non-amyloidogenic cleavage by $\alpha$ secretase to produce sAPP $\alpha$ (Kojro et al., 2001; Peters et al., 2009). Consistently, enrichment of cell membranes with PUFAs increases membrane fluidity and, subsequently, promotes nonamyloidogenic processing of APP (Yang et al., 2011). A typical Western diet (with $40 \%$ saturated fatty acids and $1 \%$ of cholesterol) fed to transgenic APP/PS1 mice increased A $\beta$, while diets supplemented with DHA decreased A $\beta$ levels (Lim et al., 2005; Oksman et al., 2006). Similarly, DHA decreased the amount of vascular A $\beta$ deposition (Hooijmans et al., 2007) and reduced cortical $A \beta$ burden in the aged Alzheimer mouse model. In this model, DHA modulated APP processing by decreasing both $\alpha$ and $\beta$-APP C-terminal fragment products and full-length APP. DHA stimulated non-amyloidogenic APP processing resulting in reduced $A \beta$ levels in cellular models of Alzheimer's disease
(Sahlin et al., 2007). DHA can decrease cholesterol de novo synthesis, shift its distribution from raft to non-raft domains, and decrease $\beta$ - and $\gamma$-secretase activity (Grimm et al., 2011). Meanwhile, our study of the effects of fatty acids on cell membrane fluidity and $\mathrm{sAPP} \alpha$ secretion in relation to degrees of unsaturation has suggested that not all unsaturated fatty acids, but only those with 4 or more double bonds, such as arachidonic acid (20:4), eicosapentaenoic acid (20:5), and DHA (22:6), increased membrane fluidity and led to an increase in $\operatorname{sAPP} \alpha$ secretion (Yang et al., 2011). Moreover, another study indicated that treatment of PSwt-1 CHO cells with oleic acid and linoleic acid increased $\gamma$-secretase activity and $A \beta$ production (Liu et al., 2004). These studies suggest that modulation of PUFAs content in cellular membrane is essential in regulating $\operatorname{sAPP} \alpha$ production partially due to their effects on membrane fluidity.

As previously mentioned, cholesterol is another essential component of the cellular membrane, which is mostly condensed in lipid rafts. Membrane cholesterol levels can be modulated by specific inhibitors of cellular biosynthesis such as statins, or it can be selectively extracted from plasma membrane by methyl- $\beta$-cyclodextrin (M $\beta C D)$. The content of cholesterol in phospholipid bilayers affects many biophysical parameters of lipid bilayers, such as thickness, thermo-mechanical properties, molecular packing, conformational freedom of phospholipid acyl chains and water, molecular oxygen permeability, membrane hydrophobicity, membrane excitability in neurons, internal dipolar potential, and membrane fluidity (Chen et al., 1999; Dumas et al., 1999; Socaciu et al., 2000; Hao et al., 2004; Arrais and Martins, 2007; Halling et al., 2008; Fantini and Yahi, 2010; Wang and Schreurs, 2010).

Intracellular cholesterol homeostasis regulates APP processing (Burns and Rebeck, 2010). A model of membrane compartmentalization has been suggested for APP in two cellular pools, one associated with the cholesterol-enriched lipid rafts, where $A \beta$ is generated, and the other outside of rafts (i.e., non-raft domains), where $\alpha$-cleavage occurs (Ehehalt et al., 2003; Colell et al., 2009). It was reported that membrane cholesterol depletion decreased the content of APP in cholesterol and sphingolipidenriched membrane microdomains and subsequently inhibited the amyloidogenic pathway to produce $A \beta$ (Kojro et al., 2001; Eckert et al., 2003). In contrast, cholesterol accumulation in the Niemann Pick type C (NPC) model cells has been shown to shift APP localization to lipid rafts (Kosicek et al., 2010). Consistent with the membrane compartmentalization model, cellular cholesterol depletion resulted in increased membrane fluidity (Kojro et al., 2001; Colell et al., 2003; Luneva et al., 2007; Rog et al., 2008). In turn, increase in membrane fluidity shifts APP processing to non-amyloidogenic cleavage by $\alpha$-secretase (Galbete et al., 2000; Colell et al., 2003; Abad-Rodriguez et al., 2004; Xiu et al., 2006; Luneva et al., 2007; Kosicek et al., 2010). The removal of cholesterol with $\mathrm{M} \beta \mathrm{CD}$ or treatment with lovastatin increased membrane fluidity, which resulted in higher expression of the $\alpha$-secretase and impaired internalization of APP (Kojro et al., 2001). The increased membrane fluidity also correlated with redistribution of cholesterol, sphingomyelin, and proteins involved in APP processing between raft and non-raft domains, and enhanced $\operatorname{sAP} \alpha$ production (Clement et al., 
2010). At the same time, cholesterol enrichment has been shown to reduce membrane fluidity (Hashimoto et al., 2006; Buffone et al., 2009). Exposure of cholesterol to astrocytes, primary neurons, and glial cultures inhibited the secretion of sAPP $\alpha$ and reduced cell viability (Racchi et al., 1997; Galbete et al., 2000; Xiu et al., 2006). Furthermore, some studies showed that cholesterol levels in the membranes were positively correlated with $\beta$-secretase activity (Liu et al., 2009), while lovastatin enhanced $\alpha$-secretase activity (Xiu et al., 2006). Cholesterol enrichment that impeded membrane fluidity may lower sAPP $\alpha$ production by hindering the interaction of the substrate with its proteases (Bodovitz and Klein, 1996). Interestingly, substitution of cholesterol by the steroid 4-cholesten-3-one induced minor change in membrane fluidity and reduced $\operatorname{sAPP} \alpha$ secretion, whereas substitution of cholesterol by lanosterol increased membrane fluidity and $\operatorname{sAPP} \alpha$ secretion (Kojro et al., 2001). These results suggest reversible effects of cholesterol on the $\alpha$-secretase activity depending on membrane fluidity.

Many studies support the notion that $\mathrm{A} \beta$ production occurs in endosomes (Kinoshita et al., 2003; Small and Gandy, 2006; Cirrito et al., 2008; Rajendran et al., 2008; Schobel et al., 2008). APP internalization from the plasma membrane enhances APP cleavage by $\beta$-secretase to increase A $\beta$ levels (Grbovic et al., 2003). In contrast, APP, lacking its cytoplasmic internalization motif, accumulates at the plasma membrane and undergoes cleavage by $\alpha$-secretase (Haass et al., 1993; Koo and Squazzo, 1994). Cholesterol increased clathrin-dependent APP endocytosis in a dose-dependent and linear manner (Cossec et al., 2010). Moreover, alterations in cholesterol transport from late endocytotic organelles to the endoplasmic reticulum had important consequences for both APP processing and the localization of $\gamma$-secretase-associated presenilins (Runz et al., 2002). An increased cholesterol level in AD has been suggested to be responsible for the enhanced internalization of clathrindependent endocytosis of APP and the overproduction of A $\beta$ (Cossec et al., 2010). Alternatively, APP internalization could be reduced by lowering cholesterol, which led to an increase in membrane fluidity, APP accumulation on the cell surface, and increased sAPP $\alpha$ secretion (Kojro et al., 2001).

Thus, summarizing findings, discussed in this chapter we can conclude that increased membrane fluidity favors nonamyloidogenic processing of APP. In turn, membrane fluidity can be increased by unsaturated PUFA with for or more double bonds (DHE, arachidonic, and eicosapentaenoic acid), or by reduction of membrane cholesterol levels (Table 3 ).

\section{Membrane Adhesion Properties and Permeability of the Blood Brain Barrier in AD}

Significant body of evidence indicates that BBB dysfunction plays critical role in the development and progression of $\mathrm{AD}$ (Snyder et al., 2014; Sweeney et al., 2015). In the early stage of $\mathrm{AD}$, microvasculature deficiencies, inflammatory reactions, $\mathrm{A} \beta$ surrounding the cerebral vasculature and endothelial dysfunctions are commonly observed (Borroni et al., 2002;
TABLE 3 | Summary of the different treatments on membrane fluidity, accumulation of APP at cell surface, and secretion of SAPP $\alpha$ and A

\begin{tabular}{|c|c|c|c|c|c|}
\hline Treatment & $\begin{array}{l}\text { Membrane } \\
\text { fluidity }\end{array}$ & $\begin{array}{l}\text { APP } \\
\text { at cell } \\
\text { surface }\end{array}$ & $\begin{array}{l}\text { Secretion } \\
\text { of } \operatorname{sAPP} \alpha\end{array}$ & $\mathbf{A} \boldsymbol{\beta}$ & References \\
\hline $\mathrm{DHA}$ & $\uparrow$ & NA & $\uparrow$ & $\downarrow$ & $\begin{array}{l}\text { Lim et al., 2005; } \\
\text { Hooijmans et al., } \\
\text { 2007; Sahlin et al., } \\
\text { 2007; Yang et al., } \\
2011\end{array}$ \\
\hline EPA & $\uparrow$ & NA & $\uparrow$ & $\mathrm{NC}$ & Yang et al., 2011 \\
\hline AA & $\uparrow$ & $\uparrow$ & $\uparrow$ & $\mathrm{NC}$ & $\begin{array}{l}\text { Yang et al., 2010, } \\
2011\end{array}$ \\
\hline $\mathrm{M} \beta \mathrm{CD}$ & $\uparrow$ & $\uparrow$ & $\uparrow$ & $\downarrow$ & Kojro et al., 2001 \\
\hline Cholesterol & $\downarrow$ & $\downarrow$ & $\downarrow$ & $\uparrow$ & $\begin{array}{l}\text { Galbete et al., } \\
\text { 2000; Colell et al., } \\
\text { 2003; Xiu et al., } \\
\text { 2006; Luneva } \\
\text { et al., 2007; Rog } \\
\text { et al., 2008; } \\
\text { Buffone et al., } \\
\text { 2009; Cossec } \\
\text { et al., 2010; } \\
\text { Marquer et al., } \\
2011\end{array}$ \\
\hline $\mathrm{C}_{6} \mathrm{H}_{5} \mathrm{OH}$ & $\uparrow$ & NA & $\uparrow$ & $\downarrow$ & Peters et al., 2009 \\
\hline PF68 & $\downarrow$ & NA & $\downarrow$ & $\uparrow$ & Peters et al., 2009 \\
\hline$A \beta$ & $\downarrow$ & NA & $\mathrm{NC}$ & $\uparrow$ & Peters et al., 2009 \\
\hline
\end{tabular}

$\uparrow$ denotes increase, $\downarrow$ denotes decrease, NC denotes no change, NA denotes data not available. Abbreviations: DHA, docosahexaenoic acid (22:6); EPA, eicosapentaenoic acid (20:5); arachidonic acid, AA (20:4); ALA, $\alpha$-linolenic acid (18:3); MBCD, methyl- $\beta$ cyclodextrin; $\mathrm{C}_{6} \mathrm{H}_{5} \mathrm{OH}$, benzyl alcohol; PF68, pluronic F68.

Montagne et al., 2015). Continuous neurovascular degeneration and accumulation of $\mathrm{A} \beta$ on blood vessels resulting in cerebral amyloid angiopathy is associated with further progression of the disease and cognitive decline. One of the features of AD brains is an accumulation of monocytes in the vessel walls and of activated microglia cells in the adjacent parenchyma, which has been found to correlate with increased deposition of $\mathrm{A} \beta$ in the cerebral vasculature (Maat-Schieman et al., 1997; Uchihara et al., 1997). It has been shown that peripheral monocytes can migrate across the blood brain barrier (BBB) and differentiate into microglia within the brain parenchyma (Mezey et al., 2000). In vitro studies have demonstrated that $A \beta$ deposition at the endothelial cell layer enhances the transmigration of monocytes (Francisco et al., 2008). Thus, increased transmigration of monocytes past the BBB is thought to drive the disease development toward exacerbation of the oxidative and inflammatory conditions characteristic of the AD brain.

Transmigration of monocytes is a sequential process having at least three distinct adhesive events: capture, tethering, and rolling; firm adhesion and arrest; and crawling on the endothelial surface to find an intercellular junction for transmigration to the target tissue. Primary capture to the endothelium and rolling is a very dynamic process mediated cooperatively by the adhesive bond between adhesion molecules (mainly P-, E-, and L-selectins) and their ligand, the shear stress imposed by blood flow, and the mechanical properties of the endothelial membrane 
(Figure 2) (Alon et al., 1997; Marshall et al., 2003; Girdhar and Shao, 2004; Sun et al., 2007). The adhesion energy between selectins and their ligands is characterized by fast binding on and off rates. If the adhesive bond pulling force is greater than $25 \mathrm{pN}$, the off rate of selectin-ligand bond will be increased (slip-bond). In contrast, if a pulling force is smaller than $25 \mathrm{pN}$, the off rate will be decreased (catch-bond) (Marshall et al., 2003). During the rolling process, the pulling force imposed on the adhesive bond by the blood flow acts upon on the monocyte and endothelial cell membrane. If a pulling force greater than $50 \mathrm{pN}$ is imposed on an endothelial surface, a tether (a cylindrical membrane tube that is tens of nanometers in diameter) will be extracted from the plasma membrane surface (Figure 2) (Girdhar and Shao, 2004). Earlier research has demonstrated that a lower membrane tether extraction force favors rolling (Girdhar and Shao, 2004; Girdhar et al., 2007). In this regards, it has been shown that enrichment of endothelial cells with cholesterol or treatment with $A \beta_{1-42}$ oligomers reduces the adhesion force for CECs, increases the expression of cell adhesion molecules and probability of adhesion leading to enhanced rate of the monocytes' transmigration (Sun et al., 2007; Askarova et al., 2013).

The biomechanical characteristics of the tight junctions is another important factor, which maintains brain homeostasis and impermeability of BBB (Vedula et al., 2005, 2009). Tight junctions are responsible for the separation of an apical and basolateral domains of cell membrane and cell polarization. The molecular biology of tight junctions has been found to be very complex, and, among all, the structure of the tight junctions in cerebral endothelium is the most elaborate. Generally, molecular structure of tight junctions is presented by several classes of transmembrane and submembrane proteins. The transmembrane proteins are occludin, claudins, junctionadhesion molecules (JAM), endothelial cell-selective molecule (ESAM), and coxsackie- and adenovirus receptor (CAR). Submembrane proteins are presented by adaptor proteins first or second order. First order adaptors are directly associated with transmembrane proteins and include $\mathrm{ZO}-1, \mathrm{ZO}-2$, and

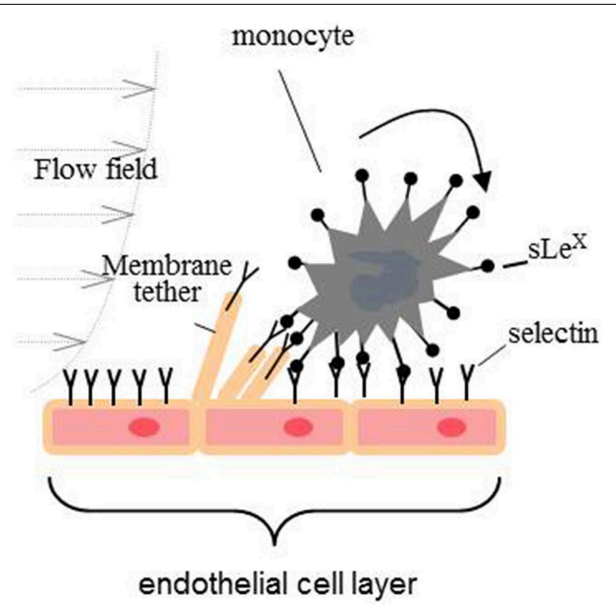

FIGURE 2 | Primary capture of monocytes to the endothelium and rolling.
ZO-3. Cingulin and coiled-coil protein are the second order adaptors which are characterized by indirect connection with transmembrane tight junction proteins (Wolburg et al., 2009).

In fact, the structure and biophysical characteristics of the tight junctions are strongly affected in the cerebrovascular cells of AD patients (Bednarczyk and Lukasiuk, 2011). In an animal model of $\mathrm{AD}$, a cholesterol-enriched diet down-regulated the expression of the occluding and ZO-1, which was strongly correlated with an elevated level of BBB leakage (Chen et al., 2008). In vitro, treatment of primary rat CECs with $A \beta_{1-42}$ for 3 days altered the expression of occluding and claudin-1, causing the relocation of plasma membrane subunits of claudin-5 and $\mathrm{ZO}-2$ to the cytoplasm. At the same time, the cytoplasmic ZO-1 and ZO-2 where evenly distributed along the plasma membrane to the points of the cell-cell contacts (Marco and Skaper, 2006).

Apolipoprotein E (apoE), a major apolipoprotein in the brain, has been shown to be involved in tight junction alteration as well (Nishitsuji et al., 2011). ApoE is a polymorphic glycoprotein playing an important role in the transportation of lipids and lipid acceptors. ApoE exists in three isoforms - ApoE2, ApoE3, and ApoE4, and among these three isoforms, ApoE4, is the greatest risk factor for late-onset $\mathrm{AD}$ and $\mathrm{A} \beta$-induced neuroinflammation (Halliday et al., 2015; Tai et al., 2015). In vitro study has demonstrated that the barrier functions of tight junctions were impaired when the CECs were reconstituted with primary astrocytes from apoE4-knock-in mice. In particular, the phosphorylation of occludin and the activation of protein kinase $\mathrm{C}(\mathrm{PKC}) \eta$ in CECs were attenuated (Nishitsuji et al., 2011).

In turn, cell membrane biophysical properties are highly dependent on the F-actin network condition and the interacting membrane and cytoskeleton integrity (Khatibzadeh et al., 2013). $\mathrm{A} \beta$ has been shown to cause formation of actin stress fibers, induce actin polymerization and increase overall cell stiffness, but significantly soften the cells in the vicinity of the plasma membrane (Mendoza-Naranjo et al., 2007; Askarova et al., 2013). To support the data that $\mathrm{A} \beta$ oligomers affect tight junction, at least partially, via altered integrity of actin network within CECs, it has been demonstrated that the force needed for separation of cellular adhesion formed by tight junction proteins significantly decreases after treating cells both with $A \beta$ and Cytochalasin-D (the actin disrupting agent) (Vedula et al., 2009). These findings suggest that the effects of $A \beta$ on actin and tight junction proteins expression and spatial distribution, cause the alteration of tight junctions' biophysics and contribute to the BBB leakage.

Strong evidence exists that cerebral endothelium regulates clearance of internal $\mathrm{A} \beta$ across the $\mathrm{BBB}$ and influx of external $A \beta$ into brain (Deane et al., 2009). $A \beta$ influx into brain from the apical surface of CEC is regulated by receptor for advanced glycosylated end products (RAGE), while lipoprotein receptor related protein (LPR1) at the basolateral surface is responsible for its efflux. In $\mathrm{AD}$ brains there is significant imbalance between these two processes leading to the elevated level of $A \beta$ in the brain's interstitial fluid and parenchyma (Deane et al., 2004, 2009). It has also been shown that CECs internalize $A \beta$ differently compared to other cells of the central nervous system (Kandimalla et al., 2009). For example, neurons internalize A $\beta$ primarily via non-endocytotic and energy independent pathway, 
while CECs demonstrate energy dependent endocytotic uptake (Kandimalla et al., 2009). Additionally, kinetics of endocytosis strongly depends on the biophysical properties of the plasma membrane: increasing membrane microviscosity slows down and eventually blocks membrane endocytosis of $A \beta$ in different cell models (Elguindi et al., 1985; Callaghan et al., 1990). The data suggest that manipulations of the $A \beta$ binding sites one the membrane and regulation of the CECs' plasma membrane biophysical properties may result in decreased $A \beta$ internalization and endocytosis (Callaghan et al., 1990).

Thus, investigations of the effects of $\mathrm{A} \beta$, cholesterol and ApoE isoforms on alterations of CECs' membrane biophysics, including imbalance in cell-cell adhesion, tight junctions integrity, CECs' endocytosis, and other important aspects of cell functions, would provide insights into the mechanisms of neuroinflammation in $\mathrm{AD}$, their correlations with cardiovascular disorders, and may offer new therapeutic strategies for $\mathrm{AD}$ patients.

\section{Conclusions}

Alterations of physical properties and lipid composition of cellular membranes have been found to impact cellular

\section{References}

Abad-Rodriguez, J., Ledesma, M. D., Craessaerts, K., Perga, S., Medina, M., Delacourte, A., et al. (2004). Neuronal membrane cholesterol loss enhances amyloid peptide generation. J. Cell Biol. 167, 953-960. doi: 10.1083/jcb.200404149

Abramowski, D., Rabe, S., Upadhaya, A. R., Reichwald, J., Danner, S., Staab, D., et al. (2012). Transgenic expression of intraneuronal $A \beta 42$ but not $A \beta 40$ leads to cellular $A \beta$ lesions, degeneration, and functional impairment without typical Alzheimer's disease pathology. J. Neurosci. 32, 1273-1283. doi: 10.1523/JNEUROSCI.4586-11.2012

Alon, R., Chen, S., Puri, K. D., Finger, E. B., and Springer, T. A. (1997). The kinetics of L-selectin tethers and the mechanics of selectin-mediated rolling. J. Cell Biol. 138, 1169-1180. doi: 10.1083/jcb.138.5.1169

Arrais, D., and Martins, J. (2007). Bilayer polarity and its thermal dependency in the $\mathrm{l}(\mathrm{o})$ and $\mathrm{l}(\mathrm{d})$ phases of binary phosphatidylcholine/cholesterol mixtures. Biochim. Biophys. Acta 1768, 2914-2922. doi: 10.1016/j.bbamem.2007.08.012

Askarova, S., Sun, Z., Sun, G. Y., Meininger, G. A., and Lee, J. C. (2013). Amyloid-beta peptide on sialyl-Lewis(X)-selectin-mediated membrane tether mechanics at the cerebral endothelial cell surface. PLOS ONE 8:e60972. doi: 10.1371/journal.pone.0060972

Ban, T., Morigaki, K., Yagi, H., Kawasaki, T., Kobayashi, A., Yuba, S., et al. (2006). Real-time and single fibril observation of the formation of amyloid beta spherulitic structures. J. Biol. Chem. 281, 33677-33683. doi: 10.1074/jbc.M606072200

Barenholz, Y. (2004). Sphingomyelin and cholesterol: from membrane biophysics and rafts to potential medical applications. Subcell. Biochem. 37, 167-215. doi: 10.1007/978-1-4757-5806-1_5

Bednarczyk, J., and Lukasiuk, K. (2011). Tight junctions in neurological diseases. Acta Neurobiol. Exp. 71, 393-408.

Bernstein, S. L., Wyttenbach, T., Baumketner, A., Shea, J.-E., Bitan, G., Teplow, D. B., et al. (2005). Amyloid OI-Protein: ВЂ\%o monomer structure and early aggregation states of AOI42 and its Pro19 Alloform. J. Am. Chem. Soc. 127, 2075-2084. doi: 10.1021/ja044531p

Bhowmik, D., Maclaughlin, C. M., Chandrakesan, M., Ramesh, P., Venkatramani, R., Walker, G. C., et al. (2014). pH changes the aggregation propensity of pathways and processes in many pathologic events of $\mathrm{AD}$. In particular, membrane's biophysical properties play a critical role in the manipulation of $\mathrm{A} \beta$ 's confirmation, aggregation, and their direct interaction with the cell membrane. In turn, $\mathrm{A} \beta$ species, as well as reactive oxygen species, also affect the CM's biophysical properties in different ways. Moreover, these membrane alterations have an impact on other cellular functions, such as amyloid precursor protein processing and cerebral endothelial adhesion and permeability. Yet the involvements of membrane biophysics in many cellular processes, e.g., $A \beta$ influx and efflux across the BBB, and NADPH oxidase activations in $\mathrm{AD}$, are still understudied. The research direction focusing on the involvements of cellular membranes in $\mathrm{AD}$ should provide insightful information for the development of treatment strategies against $\mathrm{AD}$.

\section{Acknowledgments}

We apologize to our colleagues whose relevant work could not be cited because of space limitations. This work was supported by NIH/NIA R01AG044404 (JL) and Grant of the Ministry of Education and Science of the Republic of Kazakhstan3044/GF (SA).

amyloid-[small beta] without altering the monomer conformation. Phys. Chem. Chem. Phys. 16, 885-889. doi: 10.1039/C3CP54151G

Bodovitz, S., and Klein, W. L. (1996). Cholesterol modulates alpha-secretase cleavage of amyloid precursor protein. J. Biol. Chem. 271, 4436-4440. doi: 10.1074/jbc.271.8.4436

Borroni, B., Akkawi, N., Martini, G., Colciaghi, F., Prometti, P., Rozzini, L., et al. (2002). Microvascular damage and platelet abnormalities in early Alzheimer's disease. J. Neurol. Sci. 203-204, 189-193. doi: 10.1016/S0022-510X(02)00289-7

Buffone, M. G., Verstraeten, S. V., Calamera, J. C., and Doncel, G. F. (2009). High cholesterol content and decreased membrane fluidity in human spermatozoa are associated with protein tyrosine phosphorylation and functional deficiencies. J. Androl. 30, 552-558. doi: 10.2164/jandrol.108.006551

Burns, M. P., and Rebeck, G. W. (2010). Intracellular cholesterol homeostasis and amyloid precursor protein processing. Biochim. Biophys. Acta 1801, 853-859. doi: 10.1016/j.bbalip.2010.03.004

Calder, P. C., Yaqoob, P., Harvey, D. J., Watts, A., and Newsholme, E. A. (1994). Incorporation of fatty acids by concanavalin A-stimulated lymphocytes and the effect on fatty acid composition and membrane fluidity. Biochem. J. 300(Pt 2), 509-518.

Callaghan, T. M., Metezeau, P., Gachelin, H., Redziniak, G., Milner, Y., and Goldberg, M. E. (1990). Modulation of the binding and endocytosis of concanavalin a by guinea pig keratinocytes: reversible antagonistic effects of cholesterol and phospholipid-liposomes. J. Invest. Dermatol. 94, 58-64. doi: 10.1111/1523-1747.ep12873359

Cecchi, C., Nichino, D., Zampagni, M., Bernacchioni, C., Evangelisti, E., Pensalfini, A., et al. (2009). A protective role for lipid raft cholesterol against amyloidinduced membrane damage in human neuroblastoma cells. Biochim. Biophys. Acta 1788, 2204-2216. doi: 10.1016/j.bbamem.2009.07.019

Chang, Z., Luo, Y., Zhang, Y., and Wei, G. (2010). Interactions of A $\beta 25-35$ $\beta$-Barrel-like oligomers with anionic lipid bilayer and resulting membrane leakage: an all-atom molecular dynamics study. J. Phys. Chem. B 115, 1165-1174. doi: 10.1021/jp107558e

Chen, Q., Amaral, J., Biancani, P., and Behar, J. (1999). Excess membrane cholesterol alters human gallbladder muscle contractility and membrane fluidity. Gastroenterology 116, 678-685. doi: 10.1016/S0016-5085(99) 70190-3 
Chen, X., Gawryluk, J., Wagener, J., Ghribi, O., and Geiger, J. (2008). Caffeine blocks disruption of blood brain barrier in a rabbit model of Alzheimer's disease. J. Neuroinflammation 5, 12. doi: 10.1186/1742-2094-5-12

Cheng, H., Vetrivel, K. S., Gong, P., Meckler, X., Parent, A., and Thinakaran, G. (2007). Mechanisms of disease: new therapeutic strategies for Alzheimer's disease-targeting APP processing in lipid rafts. Nat. Clin. Pract. Neurol. 3, 374-382. doi: 10.1038/ncpneuro0549

Chiti, F., and Dobson, C. M. (2006). Protein misfolding, functional amyloid, and human disease. Annu. Rev. Biochem. 75, 333-366. doi: 10.1146/annurev.biochem.75.101304.123901

Choucair, A., Chakrapani, M., Chakravarthy, B., Katsaras, J., and Johnston, L. J. (2007). Preferential accumulation of Abeta(1-42) on gel phase domains of lipid bilayers: an AFM and fluorescence study. Biochim. Biophys. Acta 1768, 146-154. doi: 10.1016/j.bbamem.2006.09.005

Cirrito, J. R., Kang, J. E., Lee, J., Stewart, F. R., Verges, D. K., Silverio, L. M., et al. (2008). Endocytosis is required for synaptic activity-dependent release of amyloid-beta in vivo. Neuron 58, 42-51. doi: 10.1016/j.neuron.2008. 02.003

Clement, A. B., Gimpl, G., and Behl, C. (2010). Oxidative stress resistance in hippocampal cells is associated with altered membrane fluidity and enhanced nonamyloidogenic cleavage of endogenous amyloid precursor protein. Free Radic. Biol. Med. 48, 1236-1241. doi: 10.1016/j.freeradbiomed.2010.02.008

Colell, A., Fernandez, A., and Fernandez-Checa, J. C. (2009). Mitochondria, cholesterol and amyloid beta peptide: a dangerous trio in Alzheimer disease. J. Bioenerg. Biomembr. 41, 417-423. doi: 10.1007/s10863-009-9242-6

Colell, A., Garcia-Ruiz, C., Lluis, J. M., Coll, O., Mari, M., and FernandezCheca, J. C. (2003). Cholesterol impairs the adenine nucleotide translocatormediated mitochondrial permeability transition through altered membrane fluidity. J. Biol. Chem. 278, 33928-33935. doi: 10.1074/jbc.M210943200

Cossec, J. C., Simon, A., Marquer, C., Moldrich, R. X., Leterrier, C., Rossier, J., et al. (2010). Clathrin-dependent APP endocytosis and Abeta secretion are highly sensitive to the level of plasma membrane cholesterol. Biochim. Biophys. Acta. 1801, 846-852. doi: 10.1016/j.bbalip.2010.05.010

Deane, R., Bell, R. D., Sagare, A., and Bv, Z. (2009). Clearance of amyloid-? peptide across the blood-brain barrier: implication for therapies in Alzheimer's disease. CNS Neurol. Disord. Drug Targets 8, 16-30. doi: 10.2174/187152709787 601867

Deane, R., Wu, Z., and Zlokovic, B. V. (2004). RAGE (Yin) Versus LRP (Yang) balance regulates Alzheimer Amyloid OI-Peptide clearance through transport across the BloodBЂ "Brain Barrier. Stroke 35, 2628-2631. doi: 10.1161/01.STR.0000143452.85382.d1

Dietrich, C., Bagatolli, L. A., Volovyk, Z. N., Thompson, N. L., Levi, M., Jacobson, K., et al. (2001). Lipid rafts reconstituted in model membranes. Biophys. J. 80, 1417-1428. doi: 10.1016/S0006-3495(01)76114-0

Dumas, D., Latger, V., Viriot, M. L., Blondel, W., and Stoltz, J. F. (1999). Membrane fluidity and oxygen diffusion in cholesterol-enriched endothelial cells. Clin. Hemorheol. Microcirc. 21, 255-261.

Dyall, S. C., and Michael-Titus, A. T. (2008). Neurological benefits of omega-3 fatty acids. Neuromolecular Med. 10, 219-235. doi: 10.1007/s12017-008-8036-z

Eckert, G. P., Kirsch, C., and Muller, W. E. (2003). Brain-membrane cholesterol in Alzheimer's disease. J. Nutr. Health Aging 7, 18-23.

Ehehalt, R., Keller, P., Haass, C., Thiele, C., and Simons, K. (2003). Amyloidogenic processing of the Alzheimer beta-amyloid precursor protein depends on lipid rafts. J. Cell Biol. 160, 113-123. doi: 10.1083/jcb.200207113

Elguindi, I., Redziniak, G., Metezeau, P., Meybeck, A., and Goldberg, M. E. (1985). Modulation of membrane receptor endocytosis by chemical effectors of membrane fluidity. Biol. Cell 54, 199-205. doi: 10.1111/j.1768322X.1985.tb00395.x

Fantini, J., and Yahi, N. (2010). Molecular insights into amyloid regulation by membrane cholesterol and sphingolipids: common mechanisms in neurodegenerative diseases. Expert Rev. Mol. Med. 12:e27. doi: $10.1017 /$ S1462399410001602

Francisco, J., Gonzalez-Velasquez, and Moss, M. A. (2008). Soluble aggregates of the amyloid- $\beta$ protein activate endothelial monolayers for adhesion and subsequent transmigration of monocyte cells. J. Neurochem. 104, 500-513. doi: 10.1111/j.1471-4159.2007.04988.x

Frisardi, V., Panza, F., Seripa, D., Farooqui, T., and Farooqui, A. A. (2011). Glycerophospholipids and glycerophospholipid-derived lipid mediators: a complex meshwork in Alzheimer's disease pathology. Prog. Lipid Res. 50, 313-330. doi: 10.1016/j.plipres.2011.06.001

Fukaya, T., Gondaira, T., Kashiyae, Y., Kotani, S., Ishikura, Y., Fujikawa, S., et al. (2007). Arachidonic acid preserves hippocampal neuron membrane fluidity in senescent rats. Neurobiol. Aging 28, 1179-1186. doi: 10.1016/j.neurobiolaging.2006.05.023

Galbete, J. L., Martin, T. R., Peressini, E., Modena, P., Bianchi, R., and Forloni, G. (2000). Cholesterol decreases secretion of the secreted form of amyloid precursor protein by interfering with glycosylation in the protein secretory pathway. Biochem. J. 348(Pt 2), 307-313. doi: 10.1042/0264-6021:3480307

Girdhar, G., Chen, Y., and Shao, J.-Y. (2007). Double-tether extraction from human umbilical vein and dermal microvascular endothelial cells. Biophys. J. 92, 1035-1045. doi: 10.1529/biophysj.106.086256

Girdhar, G., and Shao, J.-Y. (2004). Membrane tether extraction from human umbilical vein endothelial cells and its implication in leukocyte rolling. Biophys. J. 87, 3561-3568. doi: 10.1529/biophysj.104.047514

Grbovic, O. M., Mathews, P. M., Jiang, Y., Schmidt, S. D., Dinakar, R., Summers-Terio, N. B., et al. (2003). Rab5-stimulated up-regulation of the endocytic pathway increases intracellular beta-cleaved amyloid precursor protein carboxyl-terminal fragment levels and Abeta production. J. Biol. Chem. 278, 31261-31268. doi: 10.1074/jbc.M304122200

Grimm, M. O., Kuchenbecker, J., Grosgen, S., Burg, V. K., Hundsdorfer, B., Rothhaar, T. L., et al. (2011). Docosahexaenoic acid reduces amyloid beta production via multiple pleiotropic mechanisms. J. Biol. Chem. 286, 14028-14039. doi: 10.1074/jbc.M110.182329

Haass, C., Hung, A. Y., Schlossmacher, M. G., Teplow, D. B., and Selkoe, D. J. (1993). beta-Amyloid peptide and a 3-kDa fragment are derived by distinct cellular mechanisms. J. Biol. Chem. 268, 3021-3024.

Haass, C., Kaether, C., Thinakaran, G., and Sisodia, S. (2012). Trafficking and proteolytic processing of APP. Cold Spring Harb. Perspect. Med. 2:a006270. doi: 10.1101/cshperspect.a006270

Halliday, M. R., Rege, S. V., Ma, Q., Zhao, Z., Miller, C. A., Winkler, E. A., et al. (2015). Accelerated pericyte degeneration and blood-brain barrier breakdown in apolipoprotein E4 carriers with Alzheimer's disease. J. Cereb. Blood Flow Metab. doi: 10.1038/jcbfm.2015.44. [Epub ahead of print].

Halling, K. K., Ramstedt, B., and Slotte, J. P. (2008). Glycosylation induces shifts in the lateral distribution of cholesterol from ordered towards less ordered domains. Biochim. Biophys. Acta 1778, 1100-1111. doi: 10.1016/j.bbamem.2008.01.001

Hao, M., Mukherjee, S., Sun, Y., and Maxfield, F. R. (2004). Effects of cholesterol depletion and increased lipid unsaturation on the properties of endocytic membranes. J. Biol. Chem. 279, 14171-14178. doi: 10.1074/jbc.M309793200

Hashimoto, M., Hossain, S., and Shido, O. (2006). Docosahexaenoic acid but not eicosapentaenoic acid withstands dietary cholesterol-induced decreases in platelet membrane fluidity. Mol. Cell Biochem. 293, 1-8. doi: 10.1007/s11010006-0164-x

Heberle, F. A., and Feigenson, G. W. (2011). Phase separation in lipid membranes. Cold Spring Harb. Perspect. Biol. 3:a004697. doi: 10.1101/cshperspect.a004630

Heinrichs, S. C. (2010). Dietary omega-3 fatty acid supplementation for optimizing neuronal structure and function. Mol. Nutr. Food Res. 54, 447-456. doi: $10.1002 / \mathrm{mnfr} .200900201$

Hibbeln, J. R., Umhau, J. C., George, D. T., Shoaf, S. E., Linnoila, M., and Salem, N. Jr. (2000). Plasma total cholesterol concentrations do not predict cerebrospinal fluid neurotransmitter metabolites: implications for the biophysical role of highly unsaturated fatty acids. Am. J. Clin. Nutr. 71, 331S-338S.

Hicks, D. A., Nalivaeva, N. N., and Turner, A. J. (2012). Lipid rafts and Alzheimer's disease: protein-lipid interactions and perturbation of signaling. Front Physiol 3:189. doi: 10.3389/fphys.2012.00189

Hicks, J. B., Lai, Y., Sheng, W., Yang, X., Zhu, D., Sun, G. Y., et al. (2008). Amyloid- $\beta$ peptide induces temporal membrane biphasic changes in astrocytes through cytosolic phospholipase A2. Biochim. Biophys. Acta 1778, 2512-2519. doi: 10.1016/j.bbamem.2008.07.027

Hodgson, N., Trivedi, M., Muratore, C., Li, S., and Deth, R. (2013). Soluble oligomers of amyloid-beta cause changes in redox state, DNA methylation, and gene transcription by inhibiting EAAT3 mediated cysteine uptake. J. Alzheimers Dis. 36, 197-209. doi: 10.3233/JAD-130101

Hong, S., Ostaszewski, B. L., Yang, T., O'malley, T. T., Jin, M., Yanagisawa, K., et al. (2014). Soluble A $\beta$ Oligomers are rapidly sequestered from brain ISF in vivo 
and Bind GM1 Ganglioside on cellular membranes. Neuron 82, 308-319. doi: 10.1016/j.neuron.2014.02.027

Hooijmans, C. R., Rutters, F., Dederen, P. J., Gambarota, G., Veltien, A., Van Groen, T., et al. (2007). Changes in cerebral blood volume and amyloid pathology in aged Alzheimer APP/PS1 mice on a docosahexaenoic acid (DHA) diet or cholesterol enriched Typical Western Diet (TWD). Neurobiol. Dis. 28, 16-29. doi: 10.1016/j.nbd.2007.06.007

Horrocks, L. A., and Farooqui, A. A. (2004). Docosahexaenoic acid in the diet: its importance in maintenance and restoration of neural membrane function. Prostaglandins Leukot. Essent. Fatty Acids 70, 361-372. doi: 10.1016/j.plefa.2003.12.011

Hou, D.-R., Wang, Y., Xue, L., Tian, Y., Chen, K., Song, Z., et al. (2008). Effect of polygonum multiflorum on the fluidity of the mitochondria membrane and activity of COX in the hippocampus of rats with Abeta 1-40-induced Alzheimer's disease. Zhong Nan Da Xue Xue Bao. Yi Xue Ban 33, 987-992.

Hoxha, E., Boda, E., Montarolo, F., Parolisi, R., and Tempia, F. (2012). Excitability and synaptic alterations in the cerebellum of APP/PS1 mice. PLoS ONE 7:e34726-e34726. doi: 10.1371/journal.pone.0034726

Isaacs, A. M., Senn, D. B., Yuan, M., Shine, J. P., and Yankner, B. A. (2006). Acceleration of amyloid beta-peptide aggregation by physiological concentrations of calcium. J. Biol. Chem. 281, 27916-27923. doi: 10.1074/jbc.M602061200

Johnson, R. D., Schauerte, J. A., Wisser, K. C., Gafni, A., and Steel, D. G. (2011). Direct Observation of Single Amyloid- $\beta(1-40)$ oligomers on live cells: binding and growth at physiological concentrations. PLoS ONE 6:e23970. doi: 10.1371/journal.pone.0023970

Kakio, A., Nishimoto, S.-I., Yanagisawa, K., Kozutsumi, Y., and Matsuzaki, K. (2002). Interactions of Amyloid $\beta$-Protein with various Gangliosides in raft-like membranes: importance of GM1 Ganglioside-bound form as an endogenous seed for Alzheimer Amyloid †. Biochemistry 41, 7385-7390. doi: $10.1021 / \mathrm{bi0255874}$

Kandimalla, K. K., Scott, O. G., Fulzele, S., Davidson, M. W., and Poduslo, J. F. (2009). Mechanism of neuronal versus endothelial cell uptake of Alzheimer's Disease Amyloid OI Protein. PLoS ONE 4:e4627. doi: 10.1371/journal.pone.0004627

Khalifat, N., Puff, N., Dliaa, M., and Angelova, M. I. (2012). Amyloid- $\beta$ and the failure to form mitochondrial cristae: a biomimetic study involving artificial membranes. J. Alzheimer Dis. 28, 33-48. doi: 10.3233/JAD-2011-110389

Khatibzadeh, N., Spector, A. A., Brownell, W. E., and Anvari, B. (2013). Effects of plasma membrane cholesterol level and cytoskeleton F-actin on cell protrusion mechanics. PLoS ONE 8:e57147. doi: 10.1371/journal.pone.0057147

Kim, S.-I., Yi, J.-S., and Ko, Y.-G. (2006). Amyloid beta oligomerization is induced by brain lipid rafts. J. Cell. Biochem. 99, 878-889. doi: 10.1002/jcb.20978

Kinoshita, A., Fukumoto, H., Shah, T., Whelan, C. M., Irizarry, M. C., and Hyman, B. T. (2003). Demonstration by FRET of BACE interaction with the amyloid precursor protein at the cell surface and in early endosomes. J. Cell Sci. 116, 3339-3346. doi: $10.1242 /$ jcs.00643

Kitagawa, S., Kotani, K., and Kametani, F. (1990). Inhibitory mechanism of cispolyunsaturated fatty acids on platelet aggregation: the relation with their effects on Ca2+ mobilization, cyclic AMP levels and membrane fluidity. Biochim. Biophys. Acta 1054, 114-118. doi: 10.1016/0167-4889(90)90212-V

Kojro, E., Gimpl, G., Lammich, S., Marz, W., and Fahrenholz, F. (2001). Low cholesterol stimulates the nonamyloidogenic pathway by its effect on the alpha -secretase ADAM 10. Proc. Natl. Acad. Sci. U.S.A. 98, 5815-5820. doi: 10.1073/pnas.081612998

Koo, E. H., and Squazzo, S. L. (1994). Evidence that production and release of amyloid beta-protein involves the endocytic pathway. J. Biol. Chem. 269, 17386-17389.

Kosicek, M., Malnar, M., Goate, A., and Hecimovic, S. (2010). Cholesterol accumulation in Niemann Pick type C (NPC) model cells causes a shift in APP localization to lipid rafts. Biochem. Biophys. Res. Commun. 393, 404-409. doi: 10.1016/j.bbrc.2010.02.007

Kowalewski, T., and Holtzman, D. M. (1999). In situ atomic force microscopy study of Alzheimer's beta-amyloid peptide on different substrates: new insights into mechanism of beta-sheet formation. Proc. Natl. Acad. Sci. U.S.A. 96, 3688-3693. doi: 10.1073/pnas.96.7.3688

Lee, S., Zheng, X., Krishnamoorthy, J., Savelieff, M. G., Park, H. M., Brender, J. R., et al. (2014). Rational design of a structural framework with potential use to develop chemical reagents that target and modulate multiple facets of Alzheimer's disease. J. Am. Chem. Soc. 136, 299-310. doi: 10.1021/ja409801p

Lemkul, J. A., and Bevan, D. R. (2011). Lipid composition influences the release of Alzheimer's amyloid $\beta$-peptide from membranes. Protein Sci. 20, 1530-1545. doi: $10.1002 /$ pro.678

Liguori, N., Nerenberg, P. S., and Head-Gordon, T. (2013). Embedding A $\beta 42$ in heterogeneous membranes depends on cholesterol asymmetries. Biophys. J. 105, 899-910. doi: 10.1016/j.bpj.2013.06.046

Lim, G. P., Calon, F., Morihara, T., Yang, F., Teter, B., Ubeda, O., et al. (2005). A diet enriched with the omega- 3 fatty acid docosahexaenoic acid reduces amyloid burden in an aged Alzheimer mouse model. J. Neurosci. 25, 3032-3040. doi: 10.1523/JNEUROSCI.4225-04.2005

Lioudyno, M. I., Broccio, M., Sokolov, Y., Rasool, S., Wu, J., Alkire, M. T., et al. (2012). Effect of Synthetic A $\beta$ Peptide Oligomers and Fluorinated Solvents on Kv1.3 channel properties and membrane conductance. PLoS ONE 7:e35090. doi: 10.1371/journal.pone.0035090

Liu, D., Xu, Y., Feng, Y., Liu, H., Shen, X., Chen, K., et al. (2006). Inhibitor discovery targeting the intermediate structure of beta-amyloid peptide on the conformational transition pathway: implications in the aggregation mechanism of beta-amyloid peptide. Biochemistry 45, 10963-10972. doi: 10.1021/bi060955f Liu, W. W., Todd, S., Coulson, D. T., Irvine, G. B., Passmore, A. P., Mcguinness, B., et al. (2009). A novel reciprocal and biphasic relationship between membrane cholesterol and beta-secretase activity in SH-SY5Y cells and in human platelets. J. Neurochem. 108, 341-349. doi: 10.1111/j.1471-4159.2008.05753.x

Liu, Y., Yang, L., Conde-Knape, K., Beher, D., Shearman, M. S., and Shachter, N. S. (2004). Fatty acids increase presenilin-1 levels and [gamma]-secretase activity in PSwt-1 cells. J. Lipid Res. 45, 2368-2376. doi: 10.1194/jlr.M400317-JLR200

Loffhagen, N., Hartig, C., and Babel, W. (2004). Pseudomonas putida NCTC 10936 balances membrane fluidity in response to physical and chemical stress by changing the saturation degree and the trans/cis ratio of fatty acids. Biosci. Biotechnol. Biochem. 68, 317-323. doi: 10.1271/bbb.68.317

Lulevich, V., Zimmer, C. C., Hong, H.-S., Jin, L.-W., and Liu, G.-Y. (2010). Single-cell mechanics provides a sensitive and quantitative means for probing amyloid-beta peptide and neuronal cell interactions. Proc. Natl. Acad. Sci. U.S.A. 107, 13872-13877. doi: 10.1073/pnas.1008341107

Luneva, O. G., Brazhe, N. A., Maksimova, N. V., Rodnenkov, O. V., Parshina, E. Y., Bryzgalova, N. Y., et al. (2007). Ion transport, membrane fluidity and haemoglobin conformation in erythrocyte from patients with cardiovascular diseases: Role of augmented plasma cholesterol. Pathophysiology 14, 41-46. doi: 10.1016/j.pathophys.2006.12.001

Luo, J., Warmlander, S. K., Graslund, A., and Abrahams, J. P. (2014). Non-chaperone proteins can inhibit aggregation and cytotoxicity of Alzheimer amyloid beta peptide. J. Biol. Chem. 289, 27766-27775. doi: $10.1074 /$ jbc.M114.574947

Maat-Schieman, M. L., van Duinen, S. G., Rozemuller, A. J., Haan, J., and Roos, R. A. (1997). Association of vascular amyloid beta and cells of the mononuclear phagocyte system in hereditary cerebral hemorrhage with amyloidosis (Dutch) and Alzheimer disease. J. Neuropathol. Exp. Neurol. 273284. doi: 10.1097/00005072-199703000-00006

Manna, M., and Mukhopadhyay, C. (2013). Binding, conformational transition and dimerization of amyloid-beta peptide on GM1-containing ternary membrane: insights from molecular dynamics simulation. PLoS ONE 8:e71308. doi: 10.1371/journal.pone.0071308

Marco, S., and Skaper, S. D. (2006). Amyloid [beta]-peptide1-42 alters tight junction protein distribution and expression in brain microvessel endothelial cells. Neurosci. Lett. 401, 219-224. doi: 10.1016/j.neulet.2006.03.047

Marquer, C., Devauges, V., Cossec, J. C., Liot, G., Lecart, S., Saudou, F., et al. (2011). Local cholesterol increase triggers amyloid precursor protein-Bace1 clustering in lipid rafts and rapid endocytosis. FASEB J. 25, 1295-1305. doi: 10.1096/fj.10-168633

Marshall, B. T., Long, M., Piper, J. W., Mcever, R. P., Yago, T., Cheng, Z., et al. (2003). Direct observation of catch bonds involving cell-adhesion molecules. Nat. Med. 423, 190-193. doi: 10.1038/nature01605

Martín, V., Fabelo, N., Santpere, G., Puig, B., Marín, R., Ferrer, I., et al. (2010). Lipid alterations in lipid rafts from Alzheimer's disease human brain cortex. J. Alzheimer Dis. 19, 489-502. doi: 10.3233/JAD-2010-1242

Mazargui, H., Lévêque, C., Bartnik, D., Fantini, J., Gouget, T., Melone, M., et al. (2012). A synthetic amino acid substitution of Tyr10 in $A \beta$ peptide sequence 
yields a dominant negative variant in amyloidogenesis. Aging Cell 11, 530-541. doi: 10.1111/j.1474-9726.2012.00814.x

Mckoy, A. F., Chen, J., Schupbach, T., and Hecht, M. H. (2012). A novel inhibitor of amyloid beta (Abeta) peptide aggregation: from high throughput screening to efficacy in an animal model of Alzheimer disease. J. Biol. Chem. 287, 38992-39000. doi: 10.1074/jbc.M112.348037

Mclauren Dorrance, A., Graham, D., Dominiczak, A., and Fraser, R. (2000). Inhibition of nitric oxide synthesis increases erythrocyte membrane fluidity and unsaturated fatty acid content. Am. J. Hypertens. 13, 1194-1202. doi: 10.1016/S0895-7061(00)01184-5

Mclaurin, J., Yang, D., Yip, C. M., and Fraser, P. E. (2000). Review: modulating factors in amyloid-beta fibril formation. J. Struct. Biol. 130, 259-270. doi: 10.1006/jsbi.2000.4289

Mendoza-Naranjo, A., Gonzalez-Billault, C., and Maccioni, R. B. (2007). Abeta142 stimulates actin polymerization in hippocampal neurons through Racl and Cdc42 Rho GTPases. J. Cell Sci. 120, 279-288. doi: 10.1242/jcs.03323

Meraz-Rios, M. A., Franco-Bocanegra, D., Toral Rios, D., and Campos-Pena, V. (2014). Early onset Alzheimer's disease and oxidative stress. Oxid Med. Cell Longev 2014:375968. doi: 10.1155/2014/375968

Mezey, E., Chandross, K. J., Harta, G., Maki, R. A., and Mckercher, S. R. (2000). Turning blood into brain: cells bearing neuronal antigens generated in vivo from bone marrow. Science 290, 1779-1782. doi: 10.1126/science.290.5497.1779

Montagne, A., Barnes, S. R., Sweeney, M. D., Halliday, M. R., Sagare, A. P., Zhao, Z., et al. (2015). Blood-brain barrier breakdown in the aging human hippocampus. Neuron 85, 296-302. doi: 10.1016/j.neuron.2014.12.032

Nishitsuji, K., Hosono, T., Nakamura, T., Bu, G., and Michikawa, M. (2011). Apolipoprotein E regulates the integrity of tight junctions in an isoformdependent manner in an in vitro blood-brain barrier model. J. Biol. Chem. 286, 17536-17534. doi: 10.1074/jbc.M111.225532

Ogawa, M., Tsukuda, M., Yamaguchi, T., Ikeda, K., Okada, T., Yano, Y., et al. (2011). Ganglioside-mediated aggregation of amyloid $\beta$-proteins (A $\beta$ ): comparison between $A \beta-(1-42)$ and $A \beta-(1-40)$. J. Neurochem. 116, 851-857. doi: $10.1111 /$ j.1471-4159.2010.06997.x

Okada, T., Ikeda, K., Wakabayashi, M., Ogawa, M., and Matsuzaki, K. (2008). Formation of toxic Abeta(1-40) fibrils on GM1 ganglioside-containing membranes mimicking lipid rafts: polymorphisms in Abeta(1-40) fibrils. J. Mol. Biol. 382, 1066-1074. doi: 10.1016/j.jmb.2008.07.072

Oksman, M., Iivonen, H., Hogyes, E., Amtul, Z., Penke, B., Leenders, I., et al. (2006). Impact of different saturated fatty acid, polyunsaturated fatty acid and cholesterol containing diets on beta-amyloid accumulation in APP/PS1 transgenic mice. Neurobiol. Dis. 23, 563-572. doi: 10.1016/j.nbd.2006.04.013

Pan, L., and Patterson, J. C. (2013). Molecular dynamics study of Zn(abeta) and $\mathrm{Zn}$ (abeta)2. PLoS ONE 8:e70681. doi: 10.1371/journal.pone.0070681

Peters, I., Igbavboa, U., Schutt, T., Haidari, S., Hartig, U., Rosello, X., et al. (2009). The interaction of beta-amyloid protein with cellular membranes stimulates its own production. Biochim. Biophys. Acta 1788, 964-972. doi: 10.1016/j.bbamem.2009.01.012

Pike, L. J. (2006). Rafts defined: a report on the keystone symposium on lipid rafts and cell function. J. Lipid Res. 47, 1597-1598. doi: 10.1194/jlr.E600002-JLR200

Poduslo, J. F., and Howell, K. G. (2015). Unique molecular signatures of Alzheimer's disease amyloid beta peptide mutations and deletion during aggregate/oligomer/fibril formation. J. Neurosci. Res. 93, 410-423. doi: $10.1002 /$ jnr. 23507

Qiu, L., Buie, C., Reay, A., Vaughn, M. W., and Cheng, K. H. (2011). Molecular dynamics simulations reveal the protective role of cholesterol in $\beta$-amyloid protein-induced membrane disruptions in neuronal membrane mimics. J. Phys. Chem. B 115, 9795-9812. doi: 10.1021/jp2012842

Racchi, M., Baetta, R., Salvietti, N., Ianna, P., Franceschini, G., Paoletti, R., et al. (1997). Secretory processing of amyloid precursor protein is inhibited by increase in cellular cholesterol content. Biochem. J. 322(Pt 3), 893-898.

Rajendran, L., Schneider, A., Schlechtingen, G., Weidlich, S., Ries, J., Braxmeier, T., et al. (2008). Efficient Inhibition of the Alzheimer's Disease \{beta\}Secretase by membrane targeting. Science 320, 520-523. doi: 10.1126/science.11 56609

Relini, A., Cavalleri, O., Rolandi, R., and Gliozzi, A. (2009). The two-fold aspect of the interplay of amyloidogenic proteins with lipid membranes. Chem. Phys. Lipids 158, 1-9. doi: 10.1016/j.chemphyslip.2008.11.003
Rog, T., Stimson, L. M., Pasenkiewicz-Gierula, M., Vattulainen, I., and Karttunen, M. (2008). Replacing the cholesterol hydroxyl group with the ketone group facilitates sterol flip-flop and promotes membrane fluidity. J. Phys. Chem. B 112, 1946-1952. doi: 10.1021/jp075078h

Runz, H., Rietdorf, J., Tomic, I., De Bernard, M., Beyreuther, K., Pepperkok, R., et al. (2002). Inhibition of intracellular cholesterol transport alters presenilin localization and amyloid precursor protein processing in neuronal cells. J. Neurosci. 22, 1679-1689.

Sabaté, R., Espargaró, A., Barbosa-Barros, L., Ventura, S., and Estelrich, J. (2012). Effect of the surface charge of artificial model membranes on the aggregation of amyloid $\beta$-peptide. Biochimie 94, 1730-1738. doi: 10.1016/j.biochi.2012. 03.027

Sahlin, C., Pettersson, F. E., Nilsson, L. N., Lannfelt, L., and Johansson, A. S. (2007). Docosahexaenoic acid stimulates non-amyloidogenic APP processing resulting in reduced Abeta levels in cellular models of Alzheimer's disease. Eur. J. Neurosci. 26, 882-889. doi: 10.1111/j.1460-9568.2007.05719.x

Salminen, A., Ojala, J., Kauppinen, A., Kaarniranta, K., and Suuronen, T. (2009). Inflammation in Alzheimer's disease: amyloid-beta oligomers trigger innate immunity defence via pattern recognition receptors. Prog. Neurobiol. 87, 181-194. doi: 10.1016/j.pneurobio.2009.01.001

Sasahara, K., Morigaki, K., and Shinya, K. (2013). Effects of membrane interaction and aggregation of amyloid $\beta$-peptide on lipid mobility and membrane domain structure. Phys. Chem. Chem. Physics 15, 8929-8939. doi: 10.1039/c3cp4 $4517 \mathrm{~h}$

Schaefer, E. J., Bongard, V., Beiser, A. S., Lamon-Fava, S., Robins, S. J., Au, R., et al. (2006). Plasma phosphatidylcholine docosahexaenoic acid content and risk of dementia and Alzheimer disease: the Framingham Heart Study. Arch. Neurol. 63, 1545-1550. doi: 10.1001/archneur.63.11.1545

Schneider, A., Schulz-Schaeffer, W., Hartmann, T., Schulz, J. B., and Simons, M. (2006). Cholesterol depletion reduces aggregation of amyloid-beta peptide in hippocampal neurons. Neurobiol. Dis. 23, 573-577. doi: 10.1016/j.nbd.2006.04.015

Schobel, S., Neumann, S., Hertweck, M., Dislich, B., Kuhn, P. H., Kremmer, E., et al. (2008). A novel sorting nexin modulates endocytic trafficking and alpha-secretase cleavage of the amyloid precursor protein. J. Biol. Chem. 283, 14257-14268. doi: 10.1074/jbc.M801531200

Schuchardt, J. P., Huss, M., Stauss-Grabo, M., and Hahn, A. (2010). Significance of long-chain polyunsaturated fatty acids (PUFAs) for the development and behaviour of children. Eur. J. Pediatr. 169, 149-164. doi: 10.1007/s00431-0091035-8

Sengupta, K., Chatterjee, S., Pramanik, D., Dey, S. G., and Dey, A. (2014). Self-assembly of stable oligomeric and fibrillar aggregates of A[small beta] peptides relevant to Alzheimer's disease: morphology dependent $\mathrm{Cu} / \mathrm{heme}$ toxicity and inhibition of PROS generation. Dalton Trans. 43, 13377-13383. doi: 10.1039/C4DT01991A

Sinclair, A. J., Begg, D., Mathai, M., and Weisinger, R. S. (2007). Omega 3 fatty acids and the brain: review of studies in depression. Asia Pac. J. Clin. Nutr. 16(Suppl. 1), 391-397.

Small, S. A., and Gandy, S. (2006). Sorting through the cell biology of Alzheimer's disease: intracellular pathways to pathogenesis. Neuron 52, 15-31. doi: 10.1016/j.neuron.2006.09.001

Snyder, H. M., Corriveau, R. A., Craft, S., Faber, J. E., Greenberg, S. M., Knopman, D., et al. (2014). Vascular contributions to cognitive impairment and dementia including Alzheimer's disease. Alzheimers Dement. doi: 10.1016/j.jalz.2014.10.008. [Epub ahead of print].

Socaciu, C., Jessel, R., and Diehl, H. A. (2000). Competitive carotenoid and cholesterol incorporation into liposomes: effects on membrane phase transition, fluidity, polarity and anisotropy. Chem. Phys. Lipids 106, 79-88. doi: 10.1016/S0009-3084(00)00135-3

Sokolov, Y., Kozak, J. A., Kayed, R., Chanturiya, A., Glabe, C., and Hall, J. E. (2006). Soluble amyloid oligomers increase bilayer conductance by altering dielectric structure. J. Gen. Physiol. 128, 637-647. doi: 10.1085/jgp.200 609533

Sun, M., Northup, N., Marga, F., Huber, T., Byfield, F. J., Levitan, I., et al. (2007). The effect of cellular cholesterol on membrane-cytoskeleton adhesion. J. Cell Sci. 120, 2223-2231. doi: 10.1242/jcs.001370

Sweeney, M. D., Sagare, A. P., and Zlokovic, B. V. (2015). Cerebrospinal fluid biomarkers of neurovascular dysfunction in mild dementia and 
Alzheimer's disease. J. Cereb. Blood Flow Metab. 1-14. doi: 10.1038/jcbfm. 2015.76

Tai, L. M., Ghura, S., Koster, K. P., Liakaite, V., Maienschein-Cline, M., Kanabar, P., et al. (2015). APOE-modulated Abeta-induced neuroinflammation in Alzheimer's disease: current landscape, novel data, and future perspective. J. Neurochem. 133, 465-488. doi: 10.1111/jnc.13072

Thakur, G., Pao, C., Micic, M., Johnson, S., and Leblanc, R. M. (2011). Surface chemistry of lipid raft and amyloid A $\beta$ (1-40) Langmuir monolayer. Colloids Surf. B Biointerfaces 87, 369-377. doi: 10.1016/j.colsurfb.2011.05.047

Thornton, E., Vink, R., Blumbergs, P. C., and Van Den Heuvel, C. (2006). Soluble amyloid precursor protein alpha reduces neuronal injury and improves functional outcome following diffuse traumatic brain injury in rats. Brain Res. 1094, 38-46. doi: 10.1016/j.brainres.2006.03.107

Tofoleanu, F., and Buchete, N.-V. (2012). Molecular interactions of Alzheimer's A $\beta$ protofilaments with lipid Membranes. J. Mol. Biol. 421, 572-586. doi: 10.1016/j.jmb.2011.12.063

Tully, A. M., Roche, H. M., Doyle, R., Fallon, C., Bruce, I., Lawlor, B., et al. (2003). Low serum cholesteryl ester-docosahexaenoic acid levels in Alzheimer's disease: a case-control study. Br. J. Nutr. 89, 483-489. doi: 10.1079/BJN2002804

Uauy, R., Hoffman, D. R., Peirano, P., Birch, D. G., and Birch, E. E. (2001). Essential fatty acids in visual and brain development. Lipids 36, 885-895. doi: 10.1007/s11745-001-0798-1

Uchihara, T. A. H., Kondo, H., and Ikeda, K. (1997). Activated microglial cells are colocalized with perivascular deposits of amyloid-beta protein in Alzheimer's disease brain. Stroke, 1948-1950. doi: 10.1161/01.STR.28.10.1948

Vedula, S., Lim, T., Kausalya, P., Lane, E., Rajagopal, G., Hunziker, W., et al. (2009). Quantifying forces mediated by integral tight junction proteins in Cell-Cell Adhesion. Exp. Mech. 49, 3-9. doi: 10.1007/s11340-007-9113-1

Vedula, S. R., Lim, T. S., Kausalya, P. J., Hunziker, W., Rajagopal, G., and Lim, C. T. (2005). Biophysical approaches for studying the integrity and function of tight junctions. Mol. Cell Biomech. 2, 105-123.

Wang, D., and Schreurs, B. G. (2010). Dietary cholesterol modulates the excitability of rabbit hippocampal CA1 pyramidal neurons. Neurosci. Lett. 479, 327-331. doi: 10.1016/j.neulet.2010.05.090

Wang, Q., Shah, N., Zhao, J., Wang, C., Zhao, C., Liu, L., et al. (2011). Structural, morphological, and kinetic studies of [small beta]-amyloid peptide aggregation on self-assembled monolayers. Phys. Chem. Chem. Phys. 13, 15200-15210. doi: $10.1039 / \mathrm{c} 1 \mathrm{cp} 21156 \mathrm{k}$

Williamson, R., Usardi, A., Hanger, D. P., and Anderton, B. H. (2008). Membranebound beta-amyloid oligomers are recruited into lipid rafts by a fyn-dependent mechanism. FASEB J. 22, 1552-1559. doi: 10.1096/fj.07-9766com

Wolburg, H., Noell, S., Mack, A., Wolburg-Buchholz, K., and Fallier-Becker, P. (2009). Brain endothelial cells and the glio-vascular complex. Cell Tissue Res. 335, 75-96. doi: 10.1007/s00441-008-0658-9

Xiu, J., Nordberg, A., Qi, X., and Guan, Z. Z. (2006). Influence of cholesterol and lovastatin on alpha-form of secreted amyloid precursor protein and expression of alpha7 nicotinic receptor on astrocytes. Neurochem. Int. 49, 459-465. doi: 10.1016/j.neuint.2006.03.007

Yang, L., Chen, Q., Liu, Y., Zhang, J., Sun, D., Zhou, Y., et al. (2014). Se/Ru nanoparticles as inhibitors of metal-induced $\mathrm{A}$ [small beta] aggregation in Alzheimer's disease. J. Mater. Chem. B 2, 1977-1987. doi: 10.1039/C3TB21586E

Yang, X., Sheng, W., He, Y., Cui, J., Haidekker, M. A., Sun, G. Y., et al. (2010). Secretory phospholipase A2 type III enhances alpha-secretase-dependent amyloid precursor protein processing through alterations in membrane fluidity. J. Lipid Res. 51, 957-966. doi: 10.1194/jlr.M002287

Yang, X., Sheng, W., Sun, G. Y., and Lee, J. C. (2011). Effects of fatty acid unsaturation numbers on membrane fluidity and alpha-secretase-dependent amyloid precursor protein processing. Neurochem. Int. 58, 321-329. doi: 10.1016/j.neuint.2010.12.004

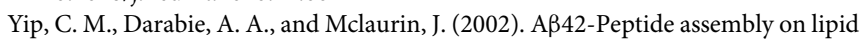
bilayers. J. Mol. Biol. 318, 97-107. doi: 10.1016/S0022-2836(02)00028-1

$\mathrm{Yu}, \mathrm{X}$., and Zheng, J. (2012). Cholesterol Promotes the Interaction of Alzheimer $\beta$-Amyloid Monomer with Lipid Bilayer. J. Mol. Biol. 421, 561-571. doi: 10.1016/j.jmb.2011.11.006

Yuyama, K., Yamamoto, N., and Yanagisawa, K. (2008). Accelerated release of exosome-associated GM1 ganglioside (GM1) by endocytic pathway abnormality: another putative pathway for GM1-induced amyloid fibril formation. J. Neurochem. 105, 217-224. doi: 10.1111/j.1471-4159.2007.05128.x

Zhao, J., Wang, Q., Liang, G., and Zheng, J. (2011). Molecular dynamics simulations of low-ordered alzheimer beta-amyloid oligomers from dimer to hexamer on self-assembled monolayers. Langmuir 27, 14876-14887. doi: 10.1021/la2027913

Zhu, D., Lai, Y., Shelat, P. B., Hu, C., Sun, G. Y., and Lee, J. C. (2006) Phospholipases A2 mediate amyloid-beta peptide-induced mitochondrial dysfunction. J. Neurosci. 26, 11111-11119. doi: 10.1523/JNEUROSCI.350506.2006

Zhu, D., Tan, K. S., Zhang, X., Sun, A. Y., Sun, G. Y., and Lee, J. C. (2005). Hydrogen peroxide alters membrane and cytoskeleton properties and increases intercellular connections in astrocytes. J. Cell Sci. 118, 3695-3703. doi: $10.1242 /$ jcs. 02507

Conflict of Interest Statement: The authors declare that the research was conducted in the absence of any commercial or financial relationships that could be construed as a potential conflict of interest.

Copyright (c) 2015 Zhu, Bungart, Yang, Zhumadilov, Lee and Askarova. This is an open-access article distributed under the terms of the Creative Commons Attribution License (CC BY). The use, distribution or reproduction in other forums is permitted, provided the original author(s) or licensor are credited and that the original publication in this journal is cited, in accordance with accepted academic practice. No use, distribution or reproduction is permitted which does not comply with these terms. 